\title{
Working
}

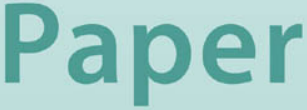




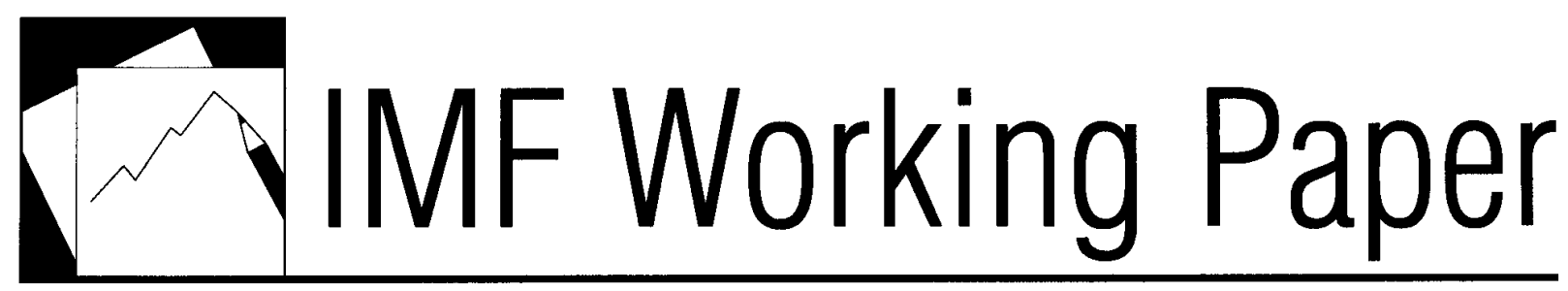

Effectiveness of Capital Controls in Selected Emerging Markets in the 2000s

Chikako Baba and Annamaria Kokenyne 


\title{
IMF Working Paper
}

Monetary and Capital Markets Department

\section{Effectiveness of Capital Controls in Selected Emerging Markets in the 2000s}

\section{Prepared by Chikako Baba and Annamaria Kokenyne ${ }^{1}$}

Authorized for distribution by Karl Habermeier

December 2011

\section{This Working Paper should not be reported as representing the views of the IMF.}

The views expressed in this Working Paper are those of the author(s) and do not necessarily represent those of the IMF or IMF policy. Working Papers describe research in progress by the author(s) and are published to elicit comments and to further debate.

\begin{abstract}
This paper estimates the effectiveness of capital controls in response to inflow surges in Brazil, Colombia, Korea, and Thailand in the 2000s. Controls are generally associated with a decrease in inflows and a lengthening of maturities, but the relationship is not statistically significant in all cases, and the effects are temporary. Controls are more successful in providing room for monetary policy than dampening currency appreciation pressures. We argue that the macroeconomic impact of capital controls depends on the extensiveness of the policy, the level of capital market development, the support provided by other policies, and the persistence of capital flows.
\end{abstract}

JEL Classification Numbers: F32, F21, F41

Keywords: capital controls, private capital flows, emerging market economies Authors’ E-Mail Addresses: cbaba@imf.org, akokeny@imf.org

\footnotetext{
${ }^{1}$ The authors are grateful to Karl Habermeier for his guidance and suggestions. We also would like to thank Atish Gosh, Asim Husain, Herman Kamil, Ceyda Oner, Tao Sun, and seminar participants at the Eastern Economic Association conference for helpful comments.
} 
I. Introduction

II. Capital Controls in Emerging Markets during the 2000s
A. Brazil
B. Colombia
C. Thailand.
D. Korea

III. Measuring the Intensity of Capital Controls.

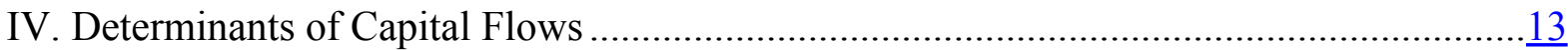

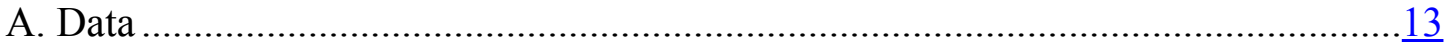

B. Results for the Pull and Push Factors...................................................................

V. Vector Autoregressive Analysis on the Effectiveness of Controls ...................................18

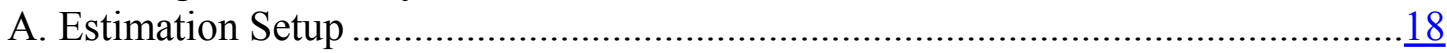

B. Results by Country …………………………............................................19

VI. Discussion and Conclusions .......................................................................................

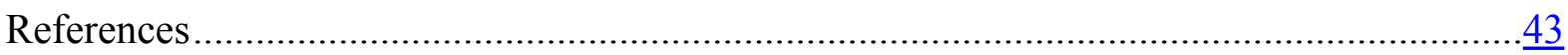

Tables

1. Private Capital Flows, 2000: Q1 to 2008: Q2 ………………………………………........

2. Effectiveness of Capital Control Policies in Selected Emerging Economies

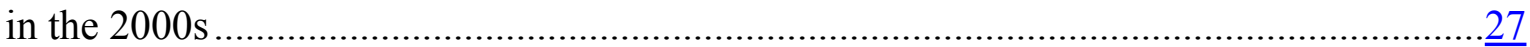

3. Regressions Explaining the Volume of Capital Flows, Brazil ..........................................28

4. Regressions Explaining the Volume of Capital Flows, Colombia ......................................29

5. Regressions Explaining the Volume of Capital Flows, Thailand ........................................

6. Regressions Explaining the Volume of Capital Flows, Korea ............................................31

Figures

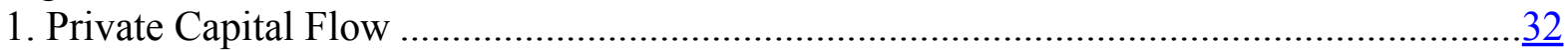

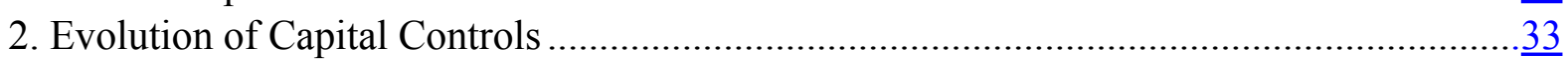

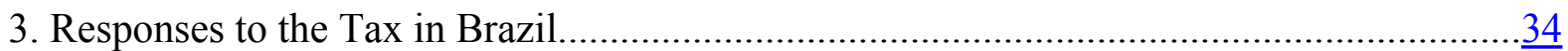

4. Responses to the Tax in Brazil, Composition of the Flows................................................

5. Responses to the Unremunerated Reserve Requirement in Colombia ................................ 35

6. Responses to the Unremunerated Reserve Requirement in Colombia, Six Months

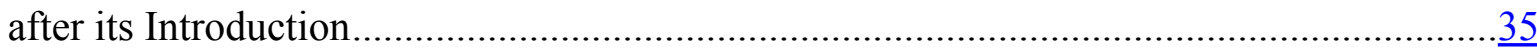

7. Responses to the Unremunerated Reserve Requirement in Colombia, Six Month after its Introduction, Composition of the Flows ………................................................

8. Responses to the Unremunerated Reserve Requirement in Thailand.................................. 36

9. Responses to the Unremunerated Reserve Requirement in Thailand, Composition of the Flows. 
10. Responses to Other Inflow Controls in Thailand.........................................................

11. Responses to the Outflow Controls in Korea...............................................................

12. Responses to the Outflow Controls in Korea, Composition of the Flows ............................

Appendices

I. Series Definition, Source, and Coverage .....................................................................

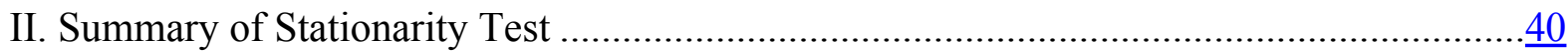

III. Selected Capital Account Management Measures......................................................... 


\section{INTRODUCTION}

Rising capital inflows into emerging market economies (EMEs) in the mid-2000s led some countries to introduce capital controls. Strong economic performance and relatively high interest rates in EMEs attracted capital inflows from advanced economies with low interest rates. When excessive, inflows raise concerns over undue appreciation pressure on the currency, which can reduce the competitiveness of the EME's export sector and raise the possibility of a sudden reversal in short-term inflows and concomitant risks to macroeconomic and financial stability. These concerns motivated some countries to introduce controls on capital inflows.

The effectiveness of capital controls is, however, unclear, as concluded by previous studies. ${ }^{2}$ A consensus arising from the literature is that capital controls can help lengthen the maturity of inflows and temporarily allow greater monetary autonomy, but they are less successful in discouraging capital inflows or easing currency appreciation pressure. These conclusions are based on extensive studies on episodes in the 1990s and on still-scant research on the policies implemented in the 2000s. Because many EMEs have opened up their capital accounts over the past decade and significantly developed their financial sector, the effectiveness of capital controls is again an important question, since capital controls are considered to be less effective in the context of sophisticated financial markets and a relatively open capital account.

This paper provides a quantitative assessment of the effect of inflow-control tightening and outflow liberalization implemented in selected EMEs in the 2000s in response to capital inflow surges. Our study focuses on episodes of foreign exchange tax in Brazil (2008), unremunerated reserve requirements (URR) in Colombia (2007-08), and Thailand (2006-08), and extensive outflow liberalization in Korea (2005-08). ${ }^{3}$ We analyze the episodes on a country-by-country basis to evaluate each country's policy separately. Country case studies also allow us to consider detailed changes in regulations that are not directly comparable across countries.

More specifically, we assess the macroeconomic impact of the polices by their ability to achieve four objectives: (i) stem capital flows; (ii) lengthen the maturity of capital inflows; (iii) allow greater room for the monetary authorities to raise interest rates; and (iv) ease currency appreciation pressure. To this end, we first construct indices tracking the intensity

\footnotetext{
${ }^{2}$ For recent surveys, see Magud and Reinhart (2007) and Ostry and others (2010). See also Ariyoshi and others (2000).

${ }^{3}$ The selected countries represent the fairly small group of countries that had a relatively open capital account and responded with capital control policies to significant surges in capital inflows. For an assessment of the effectiveness of capital controls and prudential policies in a larger group of countries, see Baba and Kokenyne (forthcoming).
} 
of temporary price-based capital controls and of other, more permanent controls on the capital account, based on reported policy changes. By separating temporary capital controls from other capital controls, we can analyze the effect of these policies separately in achieving the policy objectives. In addition, we control for various determinants of capital flows, other than capital controls, which helps in understanding country-specific factors. We quantify the impact of the policies on a time-series of capital flow data by applying a generalized method of moments (GMM) and vector autoregressive (VAR) estimation.

The estimation shows mixed results; capital controls are sometimes effective in achieving the policy objectives, while in other cases they are not.

- $\quad$ First, there is some evidence that capital controls reduced the volume and improved the maturity of capital flows. The URR in Colombia has reduced the volume of capital inflows. It also affected short-term flows and thus helped lengthen the maturity structure of inflows. Thailand's URR also affected the volume of net capital flows, but the effect materialized through increased outflows. However, the foreign exchange tax in Brazil, and outflow liberalization in Korea do not appear to have had a significant impact on the volume or the composition of flows.

- $\quad$ Second, we find that the capital control policy in Brazil and Colombia provided greater room for monetary policy to raise interest rates.

- Third, controls or outflow liberalization could not ease appreciation pressure in any of the countries.

- Fourth, other capital control policies can help achieve the objectives. For example, outflow liberalization in Thailand increased outflows and reduced net capital flows. Thailand's general inflow controls, which were tightened just before the introduction of the URR, and outflow liberalization helped maintain monetary policy autonomy.

- $\quad$ Finally, in all cases, the impact of the policies was temporary.

Considering potential reasons behind the policies' limited effectiveness, we argue that the macroeconomic impact of capital controls depends on the particular policy's extensiveness, the level of capital market development, other supporting policies, and the temporary or permanent nature of capital flows.

- $\quad$ First, capital controls that target a narrow component of capital flows may not have a noticeable macroeconomic impact. When the share of the targeted flows in total inflows is not sufficiently significant, even successfully implemented controls may not be able to lower the total volume of flows or decrease currency appreciation pressure. For example, in Colombia, the implemented policy successfully moderated 
short-term flows, but could not stem appreciation of the currency, because the majority of flows - namely, foreign direct investment (FDI) — were exempt.

- $\quad$ Second, the anticipated effect is even more difficult to achieve when the capital market is well developed, because investors can more easily find ways to circumvent the controls. For example, the sophisticated derivative market in Brazil may have decreased the effectiveness of the tax.

- Third, other capital control policies may be needed to achieve the controls' objective. For example, liberalizing outflow controls helped curb net capital flows in Thailand.

- Finally, because controls are effective only in the short term, they are more suitable for dealing with temporary surges in capital flows. To maintain effectiveness, controls may need to be adopted over time to close loopholes and minimize circumvention. However, an expansion of the controls can increase the distortions leading to adverse long-term growth effects.

Our work contributes to the existing literature on the effectiveness of capital controls in three important ways. First, it creates a new index of capital controls based on the changes in de jure capital controls. This index provides a more nuanced tool to track the evolution of capital controls than other capital control indices, which measure the existence of controls on a more aggregated level. Furthermore, the index, contrary to other existing capital control indices, allows high-frequency observations, since it tracks changes in the respective regulation monthly. Second, unlike other studies, this one separates temporary capital controls implemented in response to surges in capital inflows from other, more permanent capital controls, thus allowing separate analysis of these policies' ability to achieve their objectives. Third, by applying one framework for all the countries chosen for the analysis, it allows general conclusions to be drawn from the recent - and until now less studiedepisodes of capital control policies implemented in response to capital inflow surges.

The rest of the paper is organized as follows. In Section II, we briefly describe how each country has responded to capital inflows during the past decade. In Section III, we construct the capital control index. Section IV analyzes the determinants of capital flow volume by GMM estimation. In Section V, we present the VAR results to assess the effectiveness of capital controls on macroeconomic policy objectives. Section VI concludes. 


\section{Capital Controls in Emerging Markets during the 2000S}

Capital controls can take various forms, and their specific design differs across countries. ${ }^{4}$ Table 1 summarizes the level and composition of flows to each country in our sample. Figure 1 presents the trends of private capital flows.

\section{A. Brazil}

Foreign exchange inflows in Brazil have been increasing since the early 2000s (Figure 1). Capital inflows to Brazil increased on account of declining country risk premiums due to strong fundamentals, relatively high interest rate differentials with advanced economies, and reduced exchange rate volatility. FDI has been the largest source of inflows, approximately 2.8 percent of GDP (Table 1). However, portfolio inflows to both bond and equity markets have been growing, rising from 0.3 percent of GDP during 2000-03 to 1.2 percent of GDP during 2004-08. In addition to the relatively high interest rates and stable macroeconomic environment, portfolio inflows were further attracted by appreciation expectations in the context of a liquid and diversified domestic capital market.

Since the early 2000s, the exchange system has been liberalized significantly, reaching almost full liberalization by 2006. Controls on nonresidents' investments were relaxed in 2000 and 2001, allowing derivative transactions, purchase of stocks and bonds listed on Brazilian stock markets, and the opening of foreign bank branches. With respect to controls on outflows, in 2005, the authorities eliminated employee stock option plan ceilings in parent company investment, the limit on remittances for outward direct investment by nonfinancial private enterprises, and the authorization requirement on guarantees for certain credit operations and on personal capital movements. In 2006, they further liberalized controls on transferring funds and issuing securities abroad by residents. See Goldfajn and Minella (2005) for a more detailed description of liberalization measures between 1990 and 2004.

Concerns about the potential effects of further inflows on external competitiveness led to the introduction of capital controls in the form of taxes in 2008. Taxes up to 7 percent on foreign borrowing and 9 percent on receipts from fixed-income funds had already been implemented earlier when large, mainly portfolio, inflows had put pressure on the exchange rate in the second half of the 1990s. In 1999, a 5 percent tax was imposed on foreign borrowing with maturities shorter than 90 days. ${ }^{5}$ Following a series of foreign exchange interventions, taxes

\footnotetext{
${ }^{4}$ In this paper, capital controls are defined in accordance with the concept of restrictions on capital transactions as set out in the Organization for Economic Cooperation and Development Code of Liberalization of Capital Movements; that is, measures that restrict capital transactions and discriminate between residents and nonresidents. Thus, they generally correspond to the residency-based capital flow measures as defined in IMF (2011).
}

\footnotetext{
${ }^{5}$ See Cardoso and Goldfajn (1998) and David (2007) for assessments of the foreign exchange tax in Brazil during the 1990s.
} 
on capital account transactions were reintroduced in March 2008 at the rate of 1.5 percent on fixed-income investments. ${ }^{6}$ Funds related to equities, equity derivatives, initial public offerings, and subscription for shares remained tax exempt. In May, the tax was extended to cover "simultaneous operations" to prevent circumvention of the inflow tax. ${ }^{7}$ The tax was reduced to zero in October 2008 at the peak of the global financial crisis, when the exchange rate came under depreciation pressures. ${ }^{8}$

\section{B. Colombia}

Colombia has staged a successful economic performance since the economic crisis in 1999. On average, real GDP growth rose from -4 percent in 1999 to 7 percent in 2006, and 7.6 percent in 2007 . The peso appreciated significantly in the second half of 2006, in light of surging capital inflows (Figure 1). With the fiscal stance remaining neutral, the monetary tightening resulted in a significant hike in the policy interest rate, thus attracting even more capital inflows. Throughout the 2000s, inflows to Colombia have been predominantly in the form of FDI, accounting for 3.48 percent of GDP on average, or about 95 percent of total inflows (see Table 1). Although FDI inflows remained strong, driven by higher-than-average growth in the region, non-FDI inflows increased sharply and the exchange rate continued to appreciate in early 2007.

Until 2007, the authorities adjusted controls mainly on portfolio inflows. In 2001 and 2002, the controls took the form of regulations on the issuance of securities by residents and a ceiling on the purchase of short-term fixed-income securities by nonresidents. These measures were followed by the liberalization of securities derivatives and of controls on nonresident foreign currency deposit accounts and the lifting of the withholding tax on certain foreign exchange receipts. Between December 2004 and June 2006, a minimum-stay requirement of one year was imposed on nonresidents' portfolio investments.

Following the failed attempts to limit peso appreciation through sterilized interventions, which amounted to US\$4.5 million from January through April 2007, capital controls were

\footnotetext{
${ }^{6}$ The financial operation tax, known as the IOF (imposto sobre operações financeiras) tax, has become a permanent element of the Brazilian tax system. The rate can vary between zero and 25 percent.

${ }^{7}$ Extending the tax to "simultaneous operations" allows taxation of investments in fixed-income securities even if the investment was made in domestic currency (reais) without converting foreign currency.

${ }^{8}$ Although this paper does not cover the period after October 2008, we note that in the face of a surge in portfolio flows, a 2 percent tax on fixed-income and equity inflows was reintroduced in October 2009. To limit circumvention, in November 2009, the authorities implemented a 1.5 percent tax on certain trades involving American Depository Receipts (ADRs) issued by Brazilian companies. The tax was later increased to 6 percent and expanded to cover margin calls on derivative positions and foreign borrowing with maturities below one year. In the six months following the introduction of the tax, net inflows fell by almost half compared with the previous period, but rebounded afterward.
} 
introduced in the form of a 40 percent URR on foreign borrowing in May 2007. The URR was extended to nonresidents' portfolio investments a few weeks later in light of the accelerating portfolio inflows. Withdrawal of funds before a six-month mandatory reserve period was subject to penalties of 1.6 percent to 9.4 percent of the reserve, depending on the length of time they were held. Nonresidents' direct investments in Colombia and Colombian institutional investors' transactions, which represented a significant share in the foreign exchange market, were exempt from the URR.

To address prudential concerns related to the high foreign exchange exposure and to limit the circumvention of controls, banks' gross derivative positions were limited to 500 percent of capital. The measure aimed to reduce banks' ability to take a position against the peso, since nondeliverable forward transactions were considered to facilitate the carry trade by providing a vehicle for investors' Colombian exposure. By restricting derivative positions, it was hoped that the measure would affect capital flows and the exchange rate. The ceiling was later raised to 550 percent of capital in May 2008.

The controls, which also aimed to address macroprudential concerns, were adjusted several times in response to market developments before they were eliminated. In June 2007, equities issued abroad were exempted, thus expanding the options for securities trading without being subject to the URR. In December, the URR on initial public offerings was eliminated and early-withdrawal penalties were reduced. Although foreign borrowing declined, appreciation pressures persisted and, as a result, the URR on foreign borrowing was increased to 50 percent in May 2008, while the penalties for the early withdrawal of funds were increased in June 2008. To prevent the circumvention of controls, a two-year minimum-stay requirement was implemented on inward FDI. The controls (except for the ceiling on the gross derivative position of banks) were ultimately lifted during SeptemberOctober 2008 with the onset of the global crisis and the drying-up of external liquidity.

\section{Thailand}

Large capital inflows led to a significant appreciation of the baht and ultimately prompted the introduction of additional capital controls in 2006 (Figure 1). Although nonresidents had long been permitted to invest in bonds and money market instruments, most capital transactions were controlled in the early 2000s, typically subject to the Bank of Thailand (BOT) approval. Additional limits on nonresidents' baht deposits were introduced in 2003. Nonetheless, inflows persisted, and the baht appreciated by 9 percent between 2005:Q3 and 2006:Q3. To decrease further exchange rate appreciation, the authorities intervened extensively in the foreign exchange market, building up net reserves of US\$18 billion in 2006. Some capital controls were also tightened; in November 2006, banks' issuance and sale of bills of exchange in baht with nonresidents was limited, and in December 2006, a restriction was placed on nonresidents' short-term investments in baht financial products issued by local 
banks exceeding B 50 million without real underlying trade or investment. Ultimately, the authorities introduced controls on all capital inflows except FDI in December 2006. ${ }^{9}$

The main element of the new capital controls was a 30 percent URR. Financial institutions were required to withhold 30 percent of all foreign currency purchased or exchanged against baht exceeding US\$20,000. The amount withheld was refunded after one year on proof that the funds had been kept in Thailand for at least one year. To further discourage short-term inflows, funds transferred abroad within one year were effectively taxed at a rate of 10 percent because only two-thirds of the 30 percent withheld could be refunded.

The URR, which was adjusted several times until it was finally eliminated in early 2008, was complemented by other controls. Stock market equity inflows were exempt after one day because the introduction of the URR resulted in a sharp decline (15 percent) in equity prices. Strict limits were imposed on domestic banks' cross-border lending and borrowing in baht. By the time the URR was lifted in March 2008, the ceiling on nonresidents' investments in debt securities and loans of domestic banks had been reduced to B 10 million from B 50 million; while the limit on lending to nonresidents had been increased to B 300 million.

The authorities also extensively liberalized capital outflows to stem appreciation pressures. During 2007-08, the BOT raised the limit on overseas portfolio investments by residents, including certain institutional investors and Thai-listed companies. The ceiling on outward FDI was also raised for investments in affiliated companies in January 2007. The deadline for repatriating foreign exchange proceeds was extended in February, allowing residents to keep their proceeds abroad in foreign currency longer, thereby relieving some of the pressure on the exchange market. In the same vein, regulations governing residents' foreign currency deposits and real estate investments were relaxed in July 2007 and February 2008.

Despite gradual easing, the capital account remains largely controlled. Most outward capital transactions and many inward transactions are subject to ceilings above which BOT approval must be obtained. Foreign equity investment in nonfinancial Thai corporations may not exceed 49 percent, except for some sectors where 100 percent foreign ownership is allowed; lower limits apply to investments in financial corporations and in certain other sectors.

\section{Korea}

In the decade between the Asian and the recent global crisis, Korea has made an impressive economic recovery. Strong growth led by exports and a declining current account surplus characterized the period. Large capital inflows, attracted by stable fundamentals and

\footnotetext{
${ }^{9}$ Thaicharoen and Ananchotikul (2008) provide a detailed description of Thailand's policy measures to manage capital flows and the impact of interventions.
} 
well-developed and generally open financial markets, allowed significant reserve accumulation in the context of a generally floating exchange rate arrangement and occasional interventions since the early 2000s (Figure 1).

Short-term external debt, largely in the form of borrowing by foreign bank branches, has risen sharply since 2006 (Table 1). The borrowing was partially related to increased hedging of export revenues by local shipbuilders and some arbitrage opportunities in the sovereign bond market. Korean shipbuilders only began to hedge their foreign exchange exposure in 2004 and have increased their hedging ratio in anticipation of continued won appreciation. ${ }^{10}$ In addition, local branches of foreign banks, which were subject only to risk management standards and not to liquidity ratios or other direct regulations applicable to local banks, have borrowed dollars short-term, sold these dollars for won on the spot market, then bought certificates of deposit or other domestic bonds and sold the won forward for dollars. Against the backdrop of strong capital inflows, the authorities progressively liberalized capital outflows. Relaxation of the controls on outward investments was accelerated, partially to stem appreciation pressures, resulting in the elimination of most of the controls by 2007. The upper limit on Korean insurance companies' assets in foreign currency was increased to 30 percent in March 2005, and repatriation requirements on proceeds from residents' capital transactions abroad were relaxed in 2006. Limits were gradually increased on residents' investments abroad and finally eliminated by removing the ceilings on individuals' FDI and real estate purchases abroad in March 2006. In the same year, the previous approval requirement on certain capital transactions was changed to a notification requirement, thus reducing the administrative burden on market participants. In 2007, reporting requirements related to capital transactions were further relaxed, allowing more freedom in extending won loans to nonresidents.

\section{Measuring the Intensity of Capital Controls}

We summarize the evolution of policy measures by indices on (i) price-based inflow controls; (ii) other inflow controls; and (iii) other outflow controls. ${ }^{11}$ Each index tracks cumulative changes in regulations on capital transactions as reported in the IMF's Annual Report on Exchange Arrangements and Exchange Restrictions (AREAER) database. ${ }^{12}$ For each country, all indices are normalized at zero at the beginning of 2000 . The restrictiveness is not comparable across countries.

\footnotetext{
${ }^{10}$ Typically, exporters sell expected dollar receipts forward to domestic banks and foreign bank branches in Korea, which then borrow dollars abroad to match their own currency exposure, thereby creating a capital inflow.

${ }^{11}$ We also constructed a separate prudential measure index and confirmed the robustness of the results below. An analysis with a separate index for prudential measures is reported in Baba and Kokenyne (forthcoming).

${ }^{12}$ We also include the changes reported in Goldfajn and Minella (2005) for Brazil, and in Clements and Kamil (2009) for Colombia.
} 


\section{Price-based inflow control index}

The intensity of price-based controls, such as a URR and a foreign exchange tax, is captured as a composite of a coverage index and effective tax rates. The coverage index counts the number of asset types that are subject to the control. The index increases when the control is introduced or extended to a previously exempt type of flow. The index decreases when the control is eased or lifted. The increment of the index depends on the number of affected asset types. For example, taxing one type of asset receives a value of 1 . When the control is gradually relaxed by allowing exemptions within one type of flow, we divide the increment by the number of liberalization steps, which ensures that the coverage index stays at zero when the control is completely lifted.

Figure 2 reports the coverage index of price-based capital controls, such as URR and exchange tax. It is clear from the figure that these controls were implemented as temporary measures. Brazil's tax was introduced in March 2008 at the rate of 1.5 percent and maintained at that level until it was lifted in October 2008. Colombia introduced a six-month 40 percent URR in May 2007. Although some transactions were exempted in June and December 2007, the URR was raised to 50 percent in May 2008 and remained at that level until October 2008. Thailand's one-year 30 percent URR was implemented in December 2006. The URR was adjusted by allowing several exemptions, but the rate stayed at 30 percent until it was lifted in March 2008.

The effective tax rates are defined as follows: For the exchange tax in Brazil, the actual tax rate is used. For the URR in Colombia and Thailand, the effective tax rate refers to the tax equivalent URR rate, which is defined by

$$
\tau=i^{*} \frac{u}{1-u} \frac{k}{m}
$$

where $i^{*}$ is a foreign interest rate the investment could earn elsewhere, $u$ is the percent of flows subject to the URR, $k$ is the holding period of deposits at a central bank, and $m$ is the maturity of the investments. See De Gregorio, Edwards, and Valdés (2000) for more details. The index of price-based inflow controls in the analysis is obtained by multiplying the effective tax rate by the coverage index reported in Figure 2.

\section{Other inflow and outflow control indices}

The other inflow (outflow) control index measures the evolution of controls on nonresidents' investment in the country (residents' investment abroad). We code each change in regulations on capital transactions as reported in the "changes" section of the AREAER as 1 if the regulation is tightened or -1 if it is relaxed. When multiple measures were introduced on the same day, each measure is counted as one change. The changes are then weighted by 
the number of affected asset types. ${ }^{13}$ For example, a change that liberalizes both FDI and equity purchases by nonresidents receives a value of -2 for inflow controls. The index summarizes changes in a given month (or quarter), taking into account the number of days the regulation was in effect. For example, if the regulation went into effect the 20 th day of a month, the index considers one-third of the change to take place in that month and two-thirds in the following month. Except for the weighting method, the index is constructed in a similar way to the intensity index used in Cardoso and Goldfajn (1998).

Figure 2 plots the cumulative indices for each country, summarizing the policy measures described in the previous section. ${ }^{14}$ Inflow controls were tightened in Colombia and Thailand starting in the early 2000s, whereas Brazil and Korea eased controls on inflows during the same period. In both Brazil and Thailand, other inflow controls were tightened later, along with the introduction of a price-based control. This pattern indicates that price-based controls are usually implemented as a part of a broad policy package. Controls on outflows were liberalized in most countries, especially in Brazil and Korea, starting in the mid-2000s. Thailand shifted its focus from inflow controls to outflow liberalization in 2008.

\section{Determinants of Capital Flows}

\section{A. Data}

Our analysis covers the period 2000:Q1 to 2008:Q2 with quarterly data and January 2000 to August 2008 with monthly data, except for Colombia, for which the monthly data start in January 2004. The sample period ends before the onset of the global financial crisis, in September 2008, to avoid any potential structural break it may have created.

The data on the volume and the composition of capital flows are taken from the IMF's Balance of Payments Statistics or similar monthly statistics from national central banks. ${ }^{15}$ The balance of payments describes net transactions between residents and nonresidents. Total flows are determined from flows in direct investments, portfolio investments, derivative investments, and other investments. In the balance of payments tables, inflows refer to

\footnotetext{
${ }^{13}$ Assets are classified into 13 types: direct investments, stocks, ADRs, bonds, public bonds, money market instruments, derivatives, collective investment funds, real estate, lending, bank lending, bank investments, and other transactions.

${ }^{14}$ Appendix III summarizes the main changes in capital controls considered for the indices.

${ }^{15}$ Monthly data are available for Brazil, Colombia, and Korea. For Colombia, we use the data from the Balanza Cambiaria that cover foreign exchange transactions regardless of residency. See Clements and Kamil (2009) for differences between the Balanza Cambiaria and the balance of payments data. Due to data availability limitations, Colombia's monthly analysis starts in January 2004. The Bank of Thailand publishes the monthly series of net private capital flows, but we do not use the series in the following analysis because it does not fully separate inflows from outflows or report the composition of the flows.
} 
changes in the liabilities of each component, and outflows refer to changes in the assets of each component. All flows are expressed as a percent of GDP. ${ }^{16}$ The summary statistics on the volume and composition of the flows are reported in Table 1. Outflows are expressed with a negative sign, and a higher value in the absolute term refers to a larger amount of outflows.

Private capital flows are obtained by stripping out public sector (monetary authority and general government) flows in portfolio investment assets, other investment assets, and other investment liabilities. The government sector's portfolio investment liabilities are included because the series includes nonresident private investors' transactions in local public sector securities, which can constitute a large portion of private capital flows.

As for the maturity of flows, we consider all portfolio investments, derivative investments, and short-term other investments to be short-term flows. Remaining flows, made up of direct investments and non-short-term other investments, are considered long-term flows. For Colombia, due to the data limitations, long-term flows refer to direct investments, and short-term flows comprise portfolio investments and all other investments.

International capital flows into countries that provide better investment opportunities (pull factors) from countries with abundant capital (push factors). We choose potential determinants of capital flows based on the existing literature. The pull factors include domestic interest rates, expected appreciation of a currency, business cycles, investment risks, and current account balance. ${ }^{17}$ Corresponding variables in advanced economies are used to control for global push factors. The United States is used as the benchmark foreign country.

\section{Interest rates and expected change in the exchange rate}

Interest rates in domestic and foreign economies and an expected change in the nominal exchange rate are used to measure an expected return on international investments. We use money market interest rates in the domestic market and in the United States. The expected exchange rate is measured by a three-month forward exchange rate premium, which is defined by the difference between the forward and spot exchange rates..$^{18} \mathrm{~A}$ higher domestic

\footnotetext{
${ }^{16}$ Monthly GDP is constructed by extrapolating the quarterly GDP series from the industrial production index See Appendix 1 for more details on the series definition.

${ }^{17}$ We also tried to include a commodity price index in the regressions for Brazil and Colombia, because high commodity prices were one of the key factors driving capital flows to these countries. The commodity price index is constructed with their export share in 2005. However, the variable did not become significant and is excluded from the specification in this paper.
}

\footnotetext{
${ }^{18}$ Although forward premiums also reflect interest rate differentials, they are typically of longer term than policy rates, which are also included as a proxy for yield on short-term investments.
} 
interest rate, a lower foreign interest rate, and an expected appreciation of the currency (lower forward premium) are expected to contribute to an increase in capital flows, especially in portfolio investment flows.

\section{Business cycle}

Strong economic growth also attracts capital flows. We control for the impact of the business cycle, which is defined as a cyclical component of the log real GDP obtained by applying the Hodrick-Prescott (HP) filter. ${ }^{19}$ A country is more likely to receive capital for a higher expected profit in the future when its economy booms (positive deviations from the trend), and vice versa for the business cycle in foreign economies.

\section{Investment risks}

To control for investment risks, we include three different indicators. The first is JPMorgan's EMBI global sovereign spread. ${ }^{20}$ It tracks the difference between returns on dollardenominated sovereign debt instruments and on U.S. Treasury notes, which are considered to be risk free. The second indicator is the International Country Risk Guide (ICRG), whose composite risk ratings take into account the political, financial, and economic risks for each country. Third, we include a volatility index in the options market, the Chicago Board Options Exchange Volatility (VIX) Index, to approximate global risk appetite. A lower EMBI spread, a higher ICRG index, and a lower VIX index are all associated with lower investment risk and are likely to attract foreign capital.

\section{Current account balance}

Finally, we include current account balance as a potential determinant of capital flows. A larger current account deficit implies that more funds are available for nonresidents to invest in the capital market. Therefore, we expect a negative sign for the relationship between current account balance and capital flows.

Most variables in the analysis are defined as stationary. First-difference series are used for the capital control indices ${ }^{21}$ and the ICRG index. For a few series (in particular, real exchange rates, interest rate differentials, EMBI spreads, and the VIX index), we cannot reject the null

\footnotetext{
${ }^{19}$ The smoothing factor for the HP filter is 1,600 for the quarterly series and 14,400 for the monthly series.

${ }^{20}$ For Thailand and Korea, we do not include the EMBI spread because the corresponding series are not available for the majority of the 2000s. We implemented the regressions for the two countries with the EMBI global sovereign spread for Asia, but the variable does not become statistically significant with the expected sign.

${ }^{21}$ The capital control index traces cumulative changes. By first-differencing the index, the analysis shows the impact of changes in the regulation.
} 
hypothesis of a unit root during our sample period for all countries. In a longer sample, the nonstationary null is rejected, which implies that a short sample length is the main reason for the inability to ensure stationarity. Thus, the following results use these variables in levels. See Appendix II for a summary of the stationarity tests.

\section{B. Results for the Pull and Push Factors}

We first estimate the impact of the pull and push factors on the volume of capital flows in a reduced-form regression. Capital flows, a dependent variable, are measured by both net flows (inflows minus outflows) and inflows expressed as a percent of GDP. We also separate shortterm flows from long-term flows to test for the maturity-lengthening effect of capital controls. To address a potential endogeneity problem between capital control policy and the amount of capital flows, we report both the ordinary least squares (OLS) estimates and the GMM two-stage least squares (2SLS) estimates that employ lagged variables as instruments. For brevity, we only report the regressions with monthly data when monthly data are available. $^{22}$

Tables 3-6, which report the regression results for each of the four countries, show that most pull and push factors have the expected signs. In all of the cases, $J$-statistics do not reject the validity of the instruments used.

Interest rates and expected change in the exchange rate are significant determinants of capital flows. A higher domestic interest rate attracted capital inflows in the case of Brazil, Colombia, and Thailand. The level of the foreign interest rate is barely significant in any of the country cases, but is generally associated with a negative sign. Expected appreciation, proxied by a negative forward premium, is also a significant factor in determining financial flows for most countries. In the case of Brazil, these factors are more important for explaining the short-term flows, which is consistent with the expectation. In Korea's regressions, interest rates and the forward premium have the opposite sign, but that relationship can be attributed to the capital inflows from a third country, Japan. When controlling for the interest rate in Japan, those signs become insignificant. ${ }^{23}$

Capital flows to EMEs tend to increase during a recipient economy's upturn and decrease during an advanced economy's upturn. This relationship between business cycles and capital flows is significant for Brazil, Thailand, and Korea.

\footnotetext{
${ }^{22}$ We obtained qualitatively similar results from quarterly regressions, which are available on request.

${ }^{23}$ These results with Japan's interest rate are not reported, but are available on request. With respect to the effectiveness of Korea's outflow liberalization policy, all results here are robust if Japan is used as the benchmark country.
} 
A lower EMBI sovereign spread and a lower VIX volatility index, both of which are associated with lower risk, encouraged capital inflows to Brazil, Colombia, and Korea. The ICRG index is not strongly associated with capital flows.

Some capital controls appear to decrease the volume of capital flows significantly. We will discuss our findings from the GMM estimation along with the VAR estimation in the following section. Therefore, we only briefly describe some key results here.

- $\quad$ Brazil's tax and other capital controls did not significantly affect the flows, although they generally have the expected sign (Table 3).

- Colombia's URR seems to have reduced short-term inflows, but it didn't strongly affect total flows (Table 4).

- Colombia implemented other inflow controls before the introduction of the URR, but they were not effective.

- Thailand's liberalization of outflow controls ${ }^{24}$ seems to have contributed to an increase in outflows and a decrease in net flows with a lag (Table 5). ${ }^{25}$ At the same time, the URR was also effective in reducing the net total flows, but it did not affect total inflows.

Overall, these regressions confirm the significance of pull and push factors in explaining the volume of flows and also suggest that some capital controls were effective. The determinants of capital flows depend on the individual country, but the factors that are most frequently significant are the domestic interest rate, expected changes in the exchange rate, the domestic business cycle, the EMBI global spread, and the current account balance. ${ }^{26}$

\footnotetext{
${ }^{24}$ Thailand's regressions include the outflow control index with one-quarter lag. We included the lag because the outflow control index would otherwise find the opposite sign, and the relationship was statistically significant. That is, without the lag, the outflow liberalization is associated with increasing inflows. The relationship seems to be the result of almost simultaneous central bank removal of inflow controls (including the URR) and outflow liberalization, which makes it difficult to identify their impact separately. It is also reasonable to include the outflow liberalization index with a lag. Outflow liberalization is likely to become effective after a lag during which domestic investors adapt through accumulation of information and experience with investments abroad.

${ }^{25} \mathrm{We}$ also performed regressions for the other countries with a lag, but Thailand is the only case where a choice between lagged and contemporaneous outflow controls matters.

${ }^{26}$ We experimented with parsimonious specification by excluding some exogenous variables and confirmed the robustness of our results for the effects on capital inflows.
} 


\section{Vector Autoregressive Analysis on the EfFectiveness of Controls}

\section{A. Estimation Setup}

We use a VAR framework to assess the effectiveness of capital controls in achieving their policy targets, including lengthening the maturity of flows, maintaining a higher interest rate differential, and easing currency appreciation pressure, in addition to stemming the volume of capital inflows (Magud and Reinhart, 2007). The framework allows us to obtain the dynamic response of macroeconomic variables to controls over time.

We treat the following as potential endogenous variables: ${ }^{27}$

- $\quad$ price-based capital control index (defined by the coverage index multiplied by the effective tax rates);

- $\quad$ other inflow control index;

- other outflow control index;

- $\quad$ interest rate differential (difference in money market rates compared with a benchmark country);

- $\quad$ capital flows in percent of GDP; and

- real exchange rates relative to a benchmark country.

The ordering of variables for Cholesky decomposition is decided by the presumption that policymakers first decide on a temporary capital control measure (e.g., tax, URR, or prudential policy). Then they decide on the general restrictiveness of capital account transactions; some of the controls are designed to support the temporary measures. Given this investment environment, an interest rate differential is realized, determining the capital flows and yielding the real exchange rates. ${ }^{28}$ The simultaneity of capital controls and capital flows is addressed as long as the authorities do not respond to the capital flows immediately within the same period.

\footnotetext{
${ }^{27}$ This specification draws on De Gregorio, Edwards, and Valdés (2000). Because capital control policies typically respond to capital inflow surges, there is a potential simultaneity bias, which may underestimate the effectiveness of the controls.

${ }^{28}$ Policy actions also respond to interest rate differentials (e.g., from U.S. monetary policy) and capital inflows; this might justify a different ordering of the variables. However, because we are interested in the effect of policy changes on capital flows, the current ordering appears to be more appropriate.
} 
The estimation also includes the following exogenous variables:

- $\quad$ domestic business cycle;

- $\quad$ foreign business cycle;

- $\quad$ EMBI Global sovereign spread;

- $\quad$ ICRG composite index;

- $\quad$ VIX volatility index; and

- $\quad$ current account balance (lagged).

These are the pull and push factors used in the regressions in the previous section. To avoid the simultaneity problem, a lagged current account balance is used.

The VAR system is estimated for each country with quarterly (monthly) data for the period 2000:Q1 (January) to 2008:Q2 (August) with one lag, which is chosen by the Schwarz information criterion. The sample period is a sensitive issue, and we chose to truncate it prior to the global financial turmoil in 2008. Note that it was in October 2008, after the onset of the financial crisis, that Brazil and Colombia lifted their price-based controls. Hence, at the end of our sample period, the capital controls were still in place in these countries. Because it is generally acknowledged that the effectiveness of price-based capital controls erodes over time, our analysis may overestimate the impact of these measures by excluding a later phase of the control period and a postcontrol period. At the same time, the 2008 financial crisis initially brought about massive capital outflows from these countries and resulted in exchange rate depreciation, which reversed later on. Given that omitted unmeasurable factors, such as investors' risk aversion, seem to dominate the movement of capital flows during the crisis period, extending the analysis to cover the crisis period may also bias the estimates. Because some results are not robust when the sample covers the postcrisis period, we decided to omit it.

\section{B. Results by Country}

Impulse responses to a change in capital control measures are presented in Figures 3-13. Table 2 summarizes the results of the VAR analysis by country, measure, and objective. The impulse responses show the effect of a one standard deviation shock in capital controls on the endogenous variables. The solid lines in the figures depict the response of endogenous variables, and the dashed lines report the plus or minus two standard error bands, which yield the 95 percent confidence intervals. For each country, we apply two specifications: one includes total net capital flows, and the other decomposes the flows into short-term inflows, short-term outflows, long-term inflows, and long-term outflows. To save space, we present the full results only for the first specification. For the second specification, we focus on the 
responses of different types of flows, but we find the same qualitative implication for the other endogenous variables.

Note that in all the following cases, capital controls, especially price-based ones, do not have long-term effects. A possible explanation is that circumvention erodes the effectiveness of the controls, thus preventing the policies from having long-lasting effects. Another reason is that the control itself was implemented as a temporary measure. Because price-based policies were lifted within a few years, the policies cannot have a longer effect.

\section{Brazil}

The exchange tax shows only limited effectiveness. The impulse responses for Brazil in Figure 3 show that the tax helped maintain a higher interest rate differential but otherwise had no significant impact on the volume of net capital flows or real exchange rates. The lower left panel indicates that, in response to a one standard deviation shock to the tax index, Brazil could maintain an interest rate differential that is 0.1 percent to 0.2 percent larger than the pretax level for two to five months without attracting significant capital inflows. However, the other panels of the figure show that the total volume of capital flows did not change significantly after the introduction of the tax; hence, it could not stem the appreciation pressure. The tax is actually associated with a slight appreciation of the currency.

Nor did the tax lengthen the maturity of capital flows to Brazil. Figure 4 presents the responses of disaggregated flows. None of the flow types shows a significant change in response to the tax. This result is consistent with the GMM estimation in the previous section (Table 3) that finds the tax has no impact on either the total flows or on short-term flows.

The ineffectiveness of Brazil's exchange tax can be partially attributed to a sophisticated local derivative market that facilitated circumvention of the tax. Carvalho and Garcia (2008) analyzed the previous tax episode in the 1990s and concluded that the effectiveness of the tax in Brazil was short-lived because of the existence of sophisticated financial markets. The episode in Brazil illustrates the difficulty of imposing inflow controls in the context of already liberalized capital markets.

Although the tax and other inflow controls were both ineffective in deterring the capital inflows, the VAR shows that the outflow control index is significantly associated with the volume of long-term outflows for one month. (The corresponding impulse response function is not presented for brevity.) A negative one standard deviation shock to the outflow control index ${ }^{29}$ encouraged long-term outflows of about 1 percent of GDP. Although outflow liberalization does not show a significant effect on net flows, it is associated with a decrease

\footnotetext{
${ }^{29}$ A negative shock to the outflow control index refers to the liberalization of outflow controls.
} 
in net flows. Therefore, the outflow liberalization policy that Brazil has implemented since 2000 may have partially helped reduce the net capital flows.

\section{Colombia}

The URR in Colombia appears to have been effective in reducing net capital flows in its initial phase, although the evidence for the whole sample period is weak. In an exercise with the data covering the full sample period, from January 2004 to August 2008, we do not find any significant impact of the URR (Figure 5). However, if we truncate the sample after December 2007 and focus on the period until about six months after the introduction of the URR, the VAR shows that the URR reduced net capital flows and allowed a higher interest rate differential (Figure 6). ${ }^{30}$

In addition to initially reducing overall flows, the URR changed the composition of the flows in the short term and contributed to maintaining higher domestic interest rates. Most of the reduction in the capital flows is attributable to the change in short-term inflows (Figure 7), whereas the URR also raised short-term outflows. Because direct investments were exempt from the URR, the policy did not affect long-term flows significantly. The GMM estimation in the previous section, reported in Table 4, confirms the significant impact on the volume of short-term flows. Consequently, the URR was able to alter the composition of the capital flows, thus reducing the related vulnerabilities. The effect on the volume of non-FDI flows is in line with Clements and Kamil (2009). Concha and Galindo (2009) conclude that Colombia's inflow controls between 1998 and 2008, including the URR, were not effective in altering the volume of short-term and long-term flows. This can be reconciled by our conclusion that other inflow controls prior to the URR were ineffective, and the URR had only a short-lived impact. Our findings are in conflict with another existing work by Coelho and Gallagher (2010), which finds that the URR had an effect on the total volume but not on the composition, potentially because they do not fully control for push and pull factors. ${ }^{31}$

The fact that we find significance only in a shorter sample period indicates that the effect of the URR was short-lived. The ineffectiveness of strengthening the URR in December 2007 seems to explain such a result. Focusing on the initial phase of the URR, the impulse response shows that a one standard deviation shock to the URR policy reduced the total net

\footnotetext{
${ }^{30}$ In a separate analysis with quarterly balance of payments data for the period 2000:Q1-2008:Q2, we find a significant impact (at the 10 percent level) of the URR on capital inflows.

${ }^{31}$ Another major difference between our analysis and Coelho and Gallagher (2010) is that we use foreign exchange market data, whereas they use balance of payments data. However, the difference in the data sets does not seem to account for the conflict, because we confirmed the robustness of our findings with the quarterly balance of payments data.
} 
capital flows by 0.2 percent of GDP for two to four months and it allowed a marginally significant increase in the interest rate differential, which lasted less than two months.

As for its ability to stem appreciation pressure, the URR was not successful even in the short term (lower right panels in Figures 5 and 6). This conclusion is in line with other case studies of Colombia. Because the majority of capital flows to Colombia comprised direct investments (Table 1), which were not targeted by the URR, stemming appreciation pressures could not be reasonably anticipated.

\section{Thailand}

Thailand's URR negatively affected the volume of net capital flows (inflows minus outflows); however, it did so by increasing outflows (Figures 8 and 9). A one standard deviation shock to the URR index caused capital outflows equivalent to 2 percent of GDP for one quarter. The URR did not significantly decrease the inflows, although it was weakly associated with a reduction in short-term inflows. ${ }^{32}$ Table 5 shows the consistent results from the GMM estimation indicating that the URR was effective in stemming the total volume of flows, but did not significantly affect inflows. The effect of the URR on outflows can be accounted for by a loss of residents' confidence in domestic policies. In Thailand, the announcement of the URR in December 2006 triggered a sharp drop in stock prices, which prompted the immediate removal of controls on equities. Our results may be affected by the simultaneity of the authorities' policies: capital outflow liberalization was implemented during approximately the same period as the URR; thus, the results may reflect the effect of both policies.

Although the URR did not contribute to a higher interest rate differential or moderate appreciation pressure (Figure 8), the other controls implemented at the same time appear to have helped achieve greater monetary policy independence or a further increase in outflows. Figure 10 shows the impulse responses to a one standard deviation shock to the other inflow controls. The shock to the inflow control index, which includes some tightening measures intended to support the URR, allowed a 0.4 percent wider interest rate differential for three quarters. Similarly, the one standard deviation shock to the outflow control index allowed a 0.2 percent wider interest rate differential for two quarters. (The corresponding impulse response is not reported for brevity.) Table 5 additionally indicates that the outflow liberalization policy encouraged outflows significantly and reduced net flows, as we already mentioned in the previous section.

\footnotetext{
${ }^{32}$ We also experimentally estimated the impact on inflows with a shorter sample period, just as we did for Colombia, to focus on the initial impact of the URR. However, in the case of Thailand, such truncation does not indicate a stronger impact on the volume of inflows.
} 
Previous studies on Thailand have mixed conclusions on the effectiveness of the URR. Coelho and Gallagher (2010) show that it was effective in stemming capital flows, but had no effect on the exchange rate. Jittrapanun and Prasartset (2009) arrive at the same conclusion with respect to the exchange rate, but they show a decline in portfolio inflows as a result of the inflow controls. ${ }^{33}$ A part of the conflict seems to arise from the fact that some studies do not differentiate between inflows and net flows. Our study shows that the URR did not have the intended effect on inflows, although it effectively reduced net flows by increasing outflows. All studies agree that the URR could not stem appreciation.

\section{Korea}

Outflow liberalization in Korea does not appear to have had a significant impact. Table 6 shows that neither the inflow control index nor the outflow control index significantly affected the volume of flows after controlling for endogeneity. Figure 11 confirms the same conclusion of the VAR estimation. It further shows that outflow liberalization had no significant impact on either the interest rate differential or real exchange rates.

By looking at responses of the disaggregated flows in Figure 12, we find that outflow liberalization may have had an impact on the composition of the flows. Outflow liberalization, which is equal to a negative shock in the outflow control index, is weakly associated with a larger volume of long-term outflows and smaller short-term outflows.

This inefficiency may be attributable to the fact that the major changes in capital account restrictions were made in the $1990 \mathrm{~s}$, and those implemented in the 2000 s were relatively moderate. In fact, by utilizing a similar VAR framework, Chung and Ni (2002) analyzed the impact of inflow and outflow liberalization policies in Korea for the period between 1988 and 1999. Contrary to our results, they find that both inflows and outflows increase after a shock to the liberalization policy.

\section{Discussion AND CONCLUSIONS}

The debate over the utility of capital controls has been lively among fast-growing EMEs. The objective of introducing controls can be justified under some circumstances, but studies have cast doubts on their effectiveness. This paper provides an updated assessment of capital controls in the 2000s and shows that the effectiveness of the controls varies in achieving the specific policy objectives.

Our findings may be summarized as follows:

\footnotetext{
33 The confidence interval for the impact on portfolio inflows is relatively wide in Jittrapanun and Prasartset (2009).
} 
- $\quad$ Price-based controls on inflows were rarely effective in discouraging capital inflows or altering their composition; they were more successful in maintaining monetary policy independence. Brazil's exchange tax generally had no significant impact except for allowing higher interest rates. Colombia's URR seems to have had an initial effect on the volume and composition of capital flows, but the effectiveness quickly dissipated. It also contributed to maintaining higher domestic interest rates. Thailand's URR led to an increase in capital outflows; because this reduced net capital flows, the policy was effective, albeit not through the expected channel- that is, by reducing inflows.

- $\quad$ Other inflow controls helped achieve part of the objectives of the price-based measure - namely, allowing a higher interest rate differential in Thailand.

- Capital controls or outflow control liberalization could not stem the appreciation of the currency in any of the examined countries.

- $\quad$ Liberalizing outflow controls increased outflows, and thus helped reduce net flows, in Thailand and contributed to maintaining higher domestic interest rates for two to three quarters. However, the policy was not effective in Korea.

We draw the following lessons from these episodes.

- $\quad$ Capital controls that do not cover the majority of capital inflows, for example by exempting direct investments as in Colombia, may not have the anticipated macroeconomic impact, such as lowering the total volume of flows or easing currency appreciation pressures, even if they successfully reduce the targeted flows.

- Designing effective controls is more difficult in countries with more developed financial markets, such as Brazil, because market participants can easily find a way to circumvent them.

- $\quad$ Restricting certain flows can lead to an unintended reaction in the markets, as illustrated by the initial stock market crash followed by an overnight partial policy reversal in Thailand.

- Because controls are effective only in the short term, they are more effective in dealing with temporary surges in capital flows. For more persistent flows, they may need to be constantly adapted to close loopholes and prevent circumvention.

Finally, we note that capital controls usually come with costs and side effects that are not explicitly considered in this paper. Effectiveness in this paper is evaluated solely by a policy's ability to achieve macroeconomic objectives, but implementing capital controls 
often involves significant administrative costs, results in distortions, and may have long-term growth costs. Furthermore, some studies conclude that capital controls in the past led to misallocation of funds. Further assessment from other aspects appears to be necessary, possibly using microeconomic data, to fully evaluate the effects of capital control policies. 
Table 1. Private Capital Flows, 2000:Q1-2008:Q2

(Quarterly flows, percent of GDP)

\begin{tabular}{|c|c|c|c|c|}
\hline & Brazil & Colombia & Thailand & Korea \\
\hline Total & 2.26 & 1.83 & -0.56 & 1.99 \\
\hline (inflow) & 3.76 & 3.70 & 1.35 & 3.24 \\
\hline (outflow) & -1.50 & -1.87 & -1.92 & -2.17 \\
\hline Long-term flows $1 /$ & 1.83 & 1.92 & 1.81 & 0.18 \\
\hline (inflow) & 2.63 & 2.73 & 2.23 & 1.09 \\
\hline (outflow) & -0.81 & -0.81 & -0.43 & -0.91 \\
\hline Short-term flows $2 /$ & 0.44 & -0.09 & -2.37 & 1.81 \\
\hline (inflow) & 1.13 & 0.97 & -0.88 & 2.15 \\
\hline (outflow) & -0.69 & -1.06 & -1.49 & -1.26 \\
\hline Direct investment & 2.14 & 2.67 & 3.42 & -0.09 \\
\hline (inflow) & 2.80 & 3.48 & 3.82 & 0.73 \\
\hline (outflow) & -0.66 & -0.81 & -0.40 & -0.82 \\
\hline Portfolio investment & 0.66 & -0.35 & 0.15 & 0.70 \\
\hline (inflow) & 0.77 & 0.79 & 1.03 & 1.23 \\
\hline (outflow) & -0.11 & -1.14 & -0.88 & -1.46 \\
\hline Derivatives & -0.04 & -0.08 & -0.02 & -0.03 \\
\hline (inflow) & -0.12 & -0.08 & -0.11 & -0.59 \\
\hline (outflow) & 0.08 & 0.00 & 0.10 & 0.56 \\
\hline Other investments & -0.49 & -0.40 & -4.12 & 1.42 \\
\hline (inflow) & 0.31 & -0.48 & -3.39 & 1.86 \\
\hline (outflow) & -0.80 & 0.08 & -0.73 & -0.45 \\
\hline Other inv. Short-term & -0.18 & 0.35 & -2.51 & 1.14 \\
\hline (inflow) & 0.48 & 0.27 & -1.80 & 1.50 \\
\hline (outflow) & -0.66 & 0.08 & -0.71 & -0.36 \\
\hline
\end{tabular}

Sources: IMF, Balance of Payments Statistics; and authors' calculations.

Note: Average flows between 2000:Q1 and 2008:Q2 are reported. All flows are expressed as a percent of GDP. Values in boldface represent net overall flows. Other investment flows and portfolio outflows by monetary authorities and the general government are excluded.

1/ Long-term flows include direct investment and other non-short-term investments.

2/ Short-term flows include portfolio investments, derivatives, and other short-term investments (short-term trade credits, currency and deposits, short-term loans,

other short-term flows). 


\section{Table 2. Effectiveness of Capital Control Policies in Selected Emerging Economies in the 2000s}

\begin{tabular}{|c|c|c|c|c|c|}
\hline \multirow[t]{2}{*}{ Country } & \multirow[t]{2}{*}{ Measure } & \multicolumn{4}{|c|}{ Effect of controls } \\
\hline & & $\begin{array}{l}\text { Reduce the } \\
\text { volume of net } \\
\text { flows }\end{array}$ & $\begin{array}{c}\text { Alter the } \\
\text { composition } \\
\text { of inflows }\end{array}$ & $\begin{array}{l}\text { Reduce real } \\
\text { exchange } \\
\text { rate } \\
\text { pressures }\end{array}$ & $\begin{array}{c}\text { Increase } \\
\text { interest rate } \\
\text { differential }\end{array}$ \\
\hline $\begin{array}{l}\text { Brazil } \\
\text { (2008:Q1-Q3) } \\
(2001-07)\end{array}$ & $\begin{array}{l}1.5 \text { percent tax on } \\
\text { foreign exchange } \\
\text { transactions related to } \\
\text { fixed-income } \\
\text { investments } \\
\text { Outflow liberalization }\end{array}$ & $\begin{array}{c}\text { No, but } \\
\text { increased long- } \\
\text { term outflows }\end{array}$ & No & No & Yes \\
\hline $\begin{array}{l}\text { Colombia } \\
\text { (2007:Q2-2007:Q4) }\end{array}$ & $\begin{array}{l}40 \text { percent, six-month } \\
\text { URR on foreign } \\
\text { borrowing and portfolio } \\
\text { inflows; two-year } \\
\text { minimum stay } \\
\text { requirement for FDI; } \\
\text { limit on banks' gross } \\
\text { derivative positions to } \\
500 \text { percent of capital }\end{array}$ & Yes & $\begin{array}{l}\text { Yes(for 1-3 } \\
\text { months) }\end{array}$ & No & Yes \\
\hline Korea (2004-08) & Outflow liberalization & $\begin{array}{c}\text { No, but } \\
\text { increased long- } \\
\text { term outflows }\end{array}$ & No & No & No \\
\hline $\begin{array}{l}\text { Thailand } \\
\text { (2006:Q4-2008:Q1) }\end{array}$ & $\begin{array}{l}30 \text { percent, one-year } \\
\text { URR on foreign } \\
\text { borrowing and portfolio } \\
\text { inflows; } \\
\text { Outflow liberalization } \\
\text { Other inflow controls }\end{array}$ & $\begin{array}{l}\text { Yes (through } \\
\text { increasing } \\
\text { outflows) } \\
\text { Yes (through } \\
\text { Increased } \\
\text { outflows) 1/ } \\
\text { No }\end{array}$ & No & No & Yes \\
\hline
\end{tabular}

Source: Authors' analyses.

1/ The GMM analysis finds that outflow liberalization had a significant impact (at the 10 percent level) on the volume of net flows by increasing outflows in Thailand. 
Table 3. Regressions Explaining the Volume of Capital Flows, Brazil

\begin{tabular}{|c|c|c|c|c|c|c|c|c|}
\hline \multirow[t]{3}{*}{ Dependent variable } & \multicolumn{4}{|c|}{ Total flows } & \multicolumn{4}{|c|}{ Short term flows } \\
\hline & \multirow{2}{*}{$\begin{array}{l}\text { (net) } \\
\text { OLS }\end{array}$} & \multirow{2}{*}{$\begin{array}{l}\text { (net) } \\
2 \text { SLS }\end{array}$} & \multirow{2}{*}{$\begin{array}{l}\text { (inflow) } \\
\text { OLS }\end{array}$} & \multirow{2}{*}{$\begin{array}{l}\text { (inflow) } \\
2 \mathrm{SLS} \\
\end{array}$} & \multirow{2}{*}{$\begin{array}{l}\text { (net) } \\
\text { OLS }\end{array}$} & \multirow{2}{*}{$\begin{array}{l}\text { (net) } \\
\text { 2SLS }\end{array}$} & \multirow{2}{*}{$\begin{array}{l}\text { (inflow) } \\
\text { OLS }\end{array}$} & \multirow{2}{*}{$\begin{array}{l}\text { (inflow) } \\
\text { 2SLS }\end{array}$} \\
\hline & & & & & & & & \\
\hline \multirow[t]{2}{*}{ Constant } & -17.558 & -12.836 & -12.218 & -1.017 & -10.774 & 13.783 & 16.554 & 36.274 \\
\hline & (16.498) & (24.512) & (22.948) & $(39.945)$ & (19.494) & $(36.070)$ & (19.873) & (35.744) \\
\hline \multirow[t]{2}{*}{ Interest rate } & 0.166 & 0.435 & 0.195 & 0.591 & 0.281 & 0.382 & 0.343 & 0.642 \\
\hline & $(0.146)$ & $(0.275)$ & $(0.204)$ & $(0.372)$ & $(0.186)$ & $(0.353)$ & $(0.183)^{*}$ & $(0.365)^{*}$ \\
\hline \multirow[t]{2}{*}{ U.S. interest rate } & 0.309 & -0.939 & 0.306 & -1.496 & -0.192 & -0.656 & -0.032 & -1.485 \\
\hline & $(0.221)$ & $(0.660)$ & $(0.354)$ & $(0.840)^{*}$ & $(0.296)$ & $(0.878)$ & $(0.297)$ & $(0.773)^{*}$ \\
\hline \multirow[t]{2}{*}{ Forward premium } & -0.332 & -1.708 & -0.399 & -2.415 & -0.903 & -1.733 & -0.776 & -2.568 \\
\hline & $(0.302)$ & $(0.853)^{* *}$ & $(0.431)$ & $(1.132)^{* *}$ & $(0.398)^{* *}$ & $(1.041)^{*}$ & $(0.410)^{*}$ & $(1.038)^{* *}$ \\
\hline \multirow[t]{2}{*}{$\operatorname{Tax}$} & -0.143 & -0.499 & -0.252 & -0.776 & -0.153 & 0.108 & -0.170 & -0.382 \\
\hline & $(0.165)$ & $(0.365)$ & $(0.240)$ & $(0.494)$ & $(0.191)$ & $(0.422)$ & $(0.196)$ & $(0.452)$ \\
\hline \multirow[t]{2}{*}{ Inflow control } & 0.180 & -1.341 & 0.180 & -2.457 & -0.704 & -0.829 & -0.228 & -0.759 \\
\hline & $(0.462)$ & $(2.546)$ & $(0.467)$ & $(3.736)$ & $(0.551)$ & $(2.831)$ & $(0.466)$ & $(2.814)$ \\
\hline \multirow[t]{2}{*}{ Outflow control } & -0.201 & -0.398 & -0.091 & 1.071 & 0.400 & 5.353 & 0.264 & 2.302 \\
\hline & $(0.742)$ & $(2.653)$ & $(0.659)$ & $(3.152)$ & $(0.961)$ & (3.303) & $(0.767)$ & (2.911) \\
\hline \multirow[t]{2}{*}{ Business cycle } & 36.863 & 47.016 & 64.904 & 79.526 & 44.039 & 21.394 & 59.669 & 49.391 \\
\hline & $(21.884)^{*}$ & $(37.227)$ & $(28.186)^{* *}$ & $(54.108)$ & $(22.470)^{*}$ & $(42.195)$ & $(24.136)^{* *}$ & $(44.142)$ \\
\hline \multirow[t]{2}{*}{ U.S. business cycle } & -66.163 & -92.832 & -31.734 & -86.242 & -121.914 & -219.001 & -81.376 & -146.897 \\
\hline & $(50.523)$ & $(85.571)$ & (59.309) & $(110.502)$ & $(62.596)^{*}$ & $(96.630)^{* *}$ & $(56.662)$ & (105.498) \\
\hline \multirow[t]{2}{*}{ EMBI } & -0.006 & -0.009 & -0.004 & -0.008 & -0.008 & -0.007 & -0.007 & -0.009 \\
\hline & $(0.001)^{* *}$ & $(0.003)^{* *}$ & $(0.002)^{* *}$ & $(0.004)^{*}$ & $(0.002)^{* *}$ & $(0.003)^{* *}$ & $(0.002)^{* *}$ & $(0.004)^{* *}$ \\
\hline \multirow[t]{2}{*}{ ICRG } & 20.131 & 24.222 & 18.115 & 20.303 & 14.485 & -1.491 & -12.934 & -19.062 \\
\hline & (16.789) & (24.334) & (24.242) & (39.866) & (19.378) & $(33.266)$ & $(20.752)$ & (35.569) \\
\hline \multirow[t]{2}{*}{ Current account } & -0.834 & -2.097 & -0.581 & -2.408 & -0.438 & -1.289 & -0.428 & -2.165 \\
\hline & $(0.117)^{* *}$ & $(0.660)^{* *}$ & $(0.209)^{* *}$ & $(0.931)^{* *}$ & $(0.157)^{* *}$ & $(0.912)$ & $(0.176)^{* *}$ & $(0.799)^{* *}$ \\
\hline \multirow[t]{2}{*}{ VIX } & 0.008 & -0.214 & -0.154 & -0.509 & 0.000 & -0.354 & -0.094 & -0.513 \\
\hline & $(0.071)$ & $(0.199)$ & $(0.102)$ & $(0.275)^{*}$ & $(0.104)$ & $(0.275)$ & $(0.093)$ & $(0.256)^{* *}$ \\
\hline$R$-squared & 0.591 & 0.270 & 0.391 & -0.196 & 0.435 & -0.099 & 0.449 & -0.137 \\
\hline Adjusted $R$-squared & 0.537 & 0.174 & 0.311 & -0.354 & 0.361 & -0.244 & 0.376 & -0.287 \\
\hline Observations & 104 & 104 & 104 & 104 & 104 & 104 & 104 & 104 \\
\hline$J$-statistic & & 2.638 & & 0.646 & & 2.292 & & 0.797 \\
\hline [ $p$-value] & & {$[0.620]$} & & [0.958] & & {$[0.682]$} & & [0.939] \\
\hline
\end{tabular}

Source: Authors' calculations.

Note: White's heteroscedasticity-consistent standard errors are reported in parentheses. ** and * denote significance at the 5 percent and 10 percent level, respectively. Capital flows and current account balance are expressed as a percent of GDP. Interest rates, forward premiums, and EMBI spreads are expressed in percent. The period is 2000:M1-2008:M8. 
Table 4. Regressions Explaining the Volume of Capital Flows, Colombia

\begin{tabular}{|c|c|c|c|c|c|c|c|c|}
\hline \multirow[t]{3}{*}{ Dependent variable } & \multicolumn{4}{|c|}{ Total flows } & \multicolumn{4}{|c|}{ Short term flows } \\
\hline & \multirow{2}{*}{$\begin{array}{l}\text { (net) } \\
\text { OLS }\end{array}$} & (net) & (inflow) & (inflow) & (net) & (net) & (inflow) & (inflow) \\
\hline & & & OLS & 2SLS & OLS & 2SLS & OLS & 2SLS \\
\hline \multirow[t]{2}{*}{ Constant } & 17.990 & 16.956 & 4.771 & 2.711 & 12.747 & 10.783 & -1.178 & -3.900 \\
\hline & $(9.037)^{*}$ & $(10.701)$ & $(9.059)$ & (10.339) & $(7.154)^{*}$ & $(9.346)$ & $(6.808)$ & (7.984) \\
\hline \multirow[t]{2}{*}{ Interest rate } & 0.684 & 0.785 & 0.575 & 0.716 & 0.657 & 0.576 & 0.544 & 0.507 \\
\hline & $(0.202)^{* *}$ & $(0.303)^{* *}$ & $(0.166)^{* *}$ & $(0.275)^{* *}$ & $(0.224)^{* *}$ & $(0.303)^{*}$ & $(0.150)^{* *}$ & $(0.221)^{* *}$ \\
\hline \multirow[t]{2}{*}{ U.S. interest rate } & 0.017 & 0.049 & -0.035 & 0.005 & -0.019 & 0.004 & -0.073 & -0.050 \\
\hline & $(0.208)$ & $(0.323)$ & $(0.151)$ & $(0.245)$ & $(0.204)$ & $(0.295)$ & $(0.128)$ & $(0.195)$ \\
\hline \multirow[t]{2}{*}{ Forward premium } & -0.401 & -0.375 & -0.135 & -0.073 & -0.348 & -0.361 & -0.077 & -0.060 \\
\hline & $(0.199)^{* *}$ & $(0.230)$ & $(0.198)$ & $(0.207)$ & $(0.224)$ & $(0.267)$ & $(0.150)$ & $(0.175)$ \\
\hline \multirow[t]{2}{*}{ URR } & -0.026 & -0.044 & -0.024 & -0.051 & -0.025 & -0.029 & -0.023 & -0.035 \\
\hline & $(0.022)$ & $(0.027)$ & $(0.016)$ & $(0.022)^{* *}$ & $(0.019)$ & $(0.023)$ & $(0.013)^{*}$ & $(0.016)^{* *}$ \\
\hline \multirow[t]{2}{*}{ Inflow control } & 0.073 & 0.045 & -0.080 & -0.159 & 0.064 & 0.133 & -0.076 & -0.073 \\
\hline & $(0.101)$ & $(0.476)$ & $(0.078)$ & $(0.356)$ & $(0.133)$ & $(0.426)$ & $(0.094)$ & $(0.296)$ \\
\hline \multirow[t]{2}{*}{ Outflow control } & -0.164 & -0.591 & -0.523 & -2.098 & 0.026 & 0.195 & -0.331 & -1.253 \\
\hline & $(0.156)$ & $(1.121)$ & $(0.172)^{* *}$ & $(1.926)$ & $(0.230)$ & (1.244) & $(0.132)^{* *}$ & (1.168) \\
\hline \multirow[t]{2}{*}{ Business cycle } & 6.723 & 7.643 & 3.940 & 6.690 & 2.807 & 2.292 & 0.001 & 1.238 \\
\hline & $(4.683)$ & $(5.121)$ & (4.529) & $(5.366)$ & $(4.776)$ & $(4.891)$ & $(3.562)$ & (4.150) \\
\hline \multirow[t]{2}{*}{ U.S. business cycle } & 2.892 & 3.828 & -13.306 & -10.044 & 9.378 & 9.914 & -6.995 & -4.476 \\
\hline & (18.239) & $(19.095)$ & $(14.282)$ & (15.877) & $(15.212)$ & $(17.623)$ & $(9.101)$ & (11.335) \\
\hline \multirow[t]{2}{*}{ EMBI } & 0.001 & 0.001 & -0.001 & -0.002 & 0.001 & 0.002 & -0.001 & 0.000 \\
\hline & $(0.002)$ & $(0.003)$ & $(0.002)$ & $(0.003)$ & $(0.002)$ & $(0.004)$ & $(0.001)$ & $(0.003)$ \\
\hline \multirow[t]{2}{*}{ ICRG } & -20.570 & -20.328 & -6.050 & -5.048 & -15.737 & -13.813 & -0.505 & 1.963 \\
\hline & $(9.341)^{* *}$ & $(10.713)^{*}$ & $(9.032)$ & $(10.730)$ & $(7.155)^{* *}$ & $(9.148)$ & $(6.592)$ & $(8.026)$ \\
\hline \multirow[t]{2}{*}{ Current account } & -0.158 & -0.017 & 0.103 & 0.228 & 0.003 & -0.497 & 0.256 & -0.240 \\
\hline & $(0.228)$ & $(0.689)$ & $(0.207)$ & $(0.570)$ & $(0.265)$ & $(0.694)$ & $(0.190)$ & $(0.491)$ \\
\hline \multirow[t]{2}{*}{ VIX } & -0.111 & -0.105 & -0.085 & -0.083 & -0.123 & -0.110 & -0.095 & -0.090 \\
\hline & $(0.031)^{* *}$ & $(0.062)^{*}$ & $(0.036)^{* *}$ & $(0.055)$ & $(0.033)^{* *}$ & $(0.060)^{*}$ & $(0.028)^{* *}$ & $(0.045)^{*}$ \\
\hline$R$-squared & 0.441 & 0.423 & 0.411 & 0.285 & 0.353 & 0.295 & 0.406 & 0.245 \\
\hline Adjusted $R$-squared & 0.286 & 0.262 & 0.246 & 0.085 & 0.172 & 0.098 & 0.240 & 0.034 \\
\hline Observations & 56 & 56 & 56 & 56 & 56 & 56 & 56 & 56 \\
\hline$J$-statistic & & 2.520 & & 2.485 & & 4.393 & & 3.515 \\
\hline$[p$-value $]$ & & {$[0.774]$} & & [0.779] & & [0.494] & & [0.621] \\
\hline
\end{tabular}

Source: Authors' calculations.

Note: White's heteroscedasticity-consistent standard errors are reported in parentheses. ** and * denote significance at the 5 percent and 10 percent level, respectively. Capital flows and current account balance are expressed as a percent of GDP. Interest rates, forward premiums, and EMBI spreads are expressed in percent. The period is 2000:M1-2008:M8. 
Table 5. Regressions Explaining the Volume of Capital Flows, Thailand

\begin{tabular}{|c|c|c|c|c|c|c|c|c|}
\hline \multirow[t]{3}{*}{ Dependent variable } & \multicolumn{4}{|c|}{ Total flows } & \multicolumn{4}{|c|}{ Short term flows } \\
\hline & (net) & (net) & (inflow) & (inflow) & (net) & (net) & (inflow) & (inflow) \\
\hline & OLS & 2SLS & OLS & 2SLS & OLS & 2SLS & OLS & 2SLS \\
\hline \multirow[t]{2}{*}{ Constant } & 20.761 & -36.113 & 97.138 & 29.542 & 7.607 & -37.157 & 88.878 & 40.449 \\
\hline & $(55.548)$ & (71.377) & $(67.842)$ & (101.552) & $(51.336)$ & $(71.541)$ & $(60.295)$ & $(82.937)$ \\
\hline \multirow[t]{2}{*}{ Interest rate } & 2.252 & 2.981 & 2.616 & 3.389 & 1.408 & 2.040 & 1.610 & 2.194 \\
\hline & $(0.983)^{* *}$ & $(1.294)^{* *}$ & $(1.921)$ & (2.309) & $(1.201)$ & (1.491) & $(1.724)$ & (1.913) \\
\hline \multirow[t]{2}{*}{ U.S. interest rate } & -0.594 & -0.547 & -0.742 & -0.005 & -0.519 & -0.810 & -0.662 & -0.303 \\
\hline & $(0.916)$ & $(1.056)$ & $(1.265)$ & $(0.968)$ & $(1.027)$ & (1.201) & (1.116) & $(1.052)$ \\
\hline \multirow[t]{2}{*}{ Forward premium } & -1.508 & -1.225 & -0.971 & -0.865 & -1.292 & -0.987 & -0.825 & -0.707 \\
\hline & $(0.644)^{* *}$ & $(0.702)^{*}$ & $(0.525)^{*}$ & $(0.656)$ & $(0.633)^{*}$ & $(0.720)$ & $(0.536)$ & $(0.623)$ \\
\hline \multirow[t]{2}{*}{ URR } & -0.339 & -0.456 & -0.147 & -0.346 & -0.286 & -0.359 & -0.131 & -0.264 \\
\hline & $(0.190)^{*}$ & $(0.256)^{*}$ & $(0.232)$ & $(0.346)$ & $(0.230)$ & $(0.313)$ & $(0.223)$ & $(0.283)$ \\
\hline \multirow[t]{2}{*}{ Inflow control } & 1.051 & -0.611 & -0.276 & -2.074 & 0.984 & -0.390 & -0.265 & -1.586 \\
\hline & $(0.920)$ & (1.309) & $(0.635)$ & $(2.172)$ & $(1.120)$ & $(1.467)$ & $(0.795)$ & $(1.579)$ \\
\hline \multirow[t]{2}{*}{ Outflow control (-1) } & 1.694 & 1.672 & 0.698 & 0.957 & 1.436 & 1.279 & 0.541 & 0.655 \\
\hline & $(0.740)^{* *}$ & $(0.919)^{*}$ & $(0.925)$ & $(1.200)$ & $(0.906)$ & (1.089) & $(0.892)$ & $(1.050)$ \\
\hline \multirow[t]{2}{*}{ Business cycle } & 181.859 & 249.197 & 88.589 & 235.162 & 146.715 & 166.032 & 36.285 & 123.895 \\
\hline & $(100.476)^{*}$ & $(110.379)^{* *}$ & (110.095) & $(143.601)$ & $(104.356)$ & $(122.458)$ & $(116.933)$ & $(152.623)$ \\
\hline \multirow[t]{2}{*}{ U.S. business cycle } & -31.256 & -88.105 & 62.827 & -75.094 & 27.958 & 16.063 & 125.316 & 43.395 \\
\hline & $(152.667)$ & $(158.213)$ & $(205.487)$ & (173.567) & (169.687) & (178.795) & $(185.286)$ & $(179.961)$ \\
\hline \multirow[t]{2}{*}{ ICRG } & 0.259 & 0.157 & -0.154 & -0.092 & 0.445 & 0.274 & 0.018 & 0.016 \\
\hline & $(0.196)$ & $(0.208)$ & $(0.200)$ & $(0.286)$ & $(0.218)^{*}$ & $(0.258)$ & $(0.230)$ & $(0.276)$ \\
\hline \multirow[t]{2}{*}{ Current account } & -27.088 & 29.748 & -95.218 & -32.079 & -17.791 & 29.120 & -90.364 & -44.005 \\
\hline & $(55.081)$ & $(71.238)$ & $(66.664)$ & $(99.750)$ & $(51.001)$ & $(71.646)$ & $(57.652)$ & $(79.625)$ \\
\hline \multirow[t]{2}{*}{ VIX } & -1.055 & -0.783 & -0.630 & -0.770 & -1.035 & -0.597 & -0.611 & -0.596 \\
\hline & $(0.157)^{* *}$ & $(0.344)^{* *}$ & $(0.238)^{* *}$ & $(0.399)^{*}$ & $(0.178)^{* *}$ & $(0.404)$ & $(0.236)^{* *}$ & $(0.372)$ \\
\hline$R$-squared & 0.713 & 0.645 & 0.678 & 0.597 & 0.607 & 0.515 & 0.575 & 0.516 \\
\hline Adjusted $R$-squared & 0.570 & 0.468 & 0.517 & 0.395 & 0.410 & 0.273 & 0.362 & 0.275 \\
\hline Observations & 34 & 34 & 34 & 34 & 34 & 34 & 34 & 34 \\
\hline$J$-statistic & & 6.275 & & 7.468 & & 8.184 & & 10.176 \\
\hline [p -value] & & {$[0.393]$} & & {$[0.280]$} & & {$[0.225]$} & & [0.117] \\
\hline
\end{tabular}

Source: Authors' calculations.

Note: White's heteroscedasticity-consistent standard errors are reported in parentheses. $* *$ and $*$ denote significance at the 5 percent and 10 percent level, respectively. Capital flows and current account balance are expressed as a percent of GDP. Interest rates, forward premiums, and EMBI spreads are expressed in percent. The period is 2000:Q1-2008:Q2. 
Table 6. Regressions Explaining the Volume of Capital Flows, Korea

\begin{tabular}{|c|c|c|c|c|c|c|c|c|}
\hline \multirow[t]{3}{*}{ Dependent variable } & \multicolumn{4}{|c|}{ Total flows } & \multicolumn{4}{|c|}{ Short term flows } \\
\hline & \multirow{2}{*}{$\begin{array}{l}\text { (net) } \\
\text { OLS }\end{array}$} & \multirow{2}{*}{$\begin{array}{l}\text { (net) } \\
2 S L S\end{array}$} & \multirow{2}{*}{$\begin{array}{l}\text { (inflow) } \\
\text { OLS }\end{array}$} & \multirow{2}{*}{$\begin{array}{l}\text { (inflow) } \\
2 \text { SLS }\end{array}$} & \multirow{2}{*}{$\begin{array}{l}\text { (net) } \\
\text { OLS }\end{array}$} & \multirow{2}{*}{$\begin{array}{l}\text { (net) } \\
\text { 2SLS }\end{array}$} & \multirow{2}{*}{$\begin{array}{l}\text { (inflow) } \\
\text { OLS }\end{array}$} & \multirow{2}{*}{$\begin{array}{l}\text { (inflow) } \\
2 \text { SLS }\end{array}$} \\
\hline & & & & & & & & \\
\hline \multirow[t]{2}{*}{ Constant } & 19.497 & 17.556 & 18.329 & 12.711 & 18.947 & 21.489 & 9.176 & 9.393 \\
\hline & (13.216) & (16.318) & (14.587) & (18.043) & $(12.280)$ & (15.179) & (13.069) & (15.468) \\
\hline \multirow[t]{2}{*}{ Interest rate } & -0.686 & -0.545 & -0.009 & -0.058 & -0.516 & -0.339 & -0.187 & -0.210 \\
\hline & $(0.279)^{* * *}$ & $(0.289)^{*}$ & $(0.458)$ & $(0.607)$ & $(0.355)$ & $(0.370)$ & $(0.495)$ & $(0.590)$ \\
\hline \multirow[t]{2}{*}{ U.S. interest rate } & 0.315 & 0.245 & 0.144 & 0.129 & 0.262 & 0.128 & 0.265 & 0.209 \\
\hline & $(0.121)^{* *}$ & $(0.124)^{*}$ & $(0.225)$ & $(0.256)$ & $(0.154)$ & $(0.156)$ & $(0.220)$ & $(0.240)$ \\
\hline \multirow[t]{2}{*}{ Forward premium } & 1.564 & 1.235 & 0.378 & 0.123 & 1.313 & 0.825 & 0.880 & 0.613 \\
\hline & $(0.410)^{* *}$ & $(0.465)^{* *}$ & $(0.970)$ & (1.108) & $(0.556)^{* *}$ & $(0.663)$ & $(0.933)$ & (1.061) \\
\hline \multirow[t]{2}{*}{ Inflow control } & 0.271 & 0.320 & -0.629 & -2.061 & 0.529 & -0.287 & -0.426 & -2.189 \\
\hline & $(0.378)$ & $(1.175)$ & $(0.504)$ & $(2.778)$ & $(0.282)^{*}$ & $(1.451)$ & $(0.425)$ & (2.289) \\
\hline \multirow[t]{2}{*}{ Outflow control } & -0.016 & -0.090 & 0.380 & 1.619 & -0.152 & -0.293 & 0.275 & 1.100 \\
\hline & $(0.128)$ & $(0.627)$ & $(0.143)^{* *}$ & (1.359) & $(0.111)$ & $(0.736)$ & $(0.118)^{* *}$ & (1.092) \\
\hline \multirow[t]{2}{*}{ Business cycle } & 6.636 & 6.365 & 10.581 & 6.408 & 9.789 & 10.756 & 12.972 & 11.147 \\
\hline & $(3.504)^{*}$ & (3.992) & $(4.948)^{* *}$ & (7.731) & $(4.217)^{* *}$ & $(5.200)^{*}$ & $(5.085)^{* *}$ & $(6.392) *$ \\
\hline \multirow[t]{2}{*}{ U.S. business cycle } & -2.310 & -5.736 & -45.578 & -28.319 & -3.135 & -3.083 & -48.124 & -32.461 \\
\hline & (19.047) & (22.109) & $(24.225)^{*}$ & $(45.436)$ & $(24.839)$ & (27.235) & $(28.909)$ & $(42.152)$ \\
\hline \multirow[t]{2}{*}{ ICRG } & -16.141 & -14.773 & -15.316 & -8.924 & -16.171 & -19.446 & -6.597 & -6.322 \\
\hline & (13.204) & $(16.278)$ & (14.475) & (17.584) & $(12.315)$ & $(15.185)$ & (12.968) & (15.236) \\
\hline \multirow[t]{2}{*}{ Current account } & -0.583 & -0.252 & -0.332 & -0.471 & -0.618 & -0.133 & -0.363 & -0.378 \\
\hline & $(0.150)^{* * *}$ & $(0.243)$ & $(0.217)$ & $(0.418)$ & $(0.208)^{* *}$ & $(0.256)$ & $(0.245)$ & $(0.396)$ \\
\hline \multirow[t]{2}{*}{ VIX } & -0.046 & -0.040 & -0.095 & -0.100 & -0.045 & -0.034 & -0.081 & -0.080 \\
\hline & $(0.021)^{* *}$ & $(0.023)^{*}$ & $(0.031)^{* *}$ & $(0.032)^{* *}$ & $(0.027)$ & $(0.030)$ & $(0.031)^{* *}$ & $(0.032)^{* *}$ \\
\hline$R$-squared & 0.263 & 0.220 & 0.230 & -0.116 & 0.202 & 0.079 & 0.212 & 0.078 \\
\hline Adjusted $R$-squared & 0.184 & 0.136 & 0.147 & -0.236 & 0.116 & -0.020 & 0.127 & -0.021 \\
\hline Observations & 104 & 104 & 104 & 104 & 104 & 104 & 104 & 104 \\
\hline$J$-statistic & & 1.909 & & 3.749 & & 0.324 & & 2.959 \\
\hline [ $p$-value] & & {$[0.862]$} & & {$[0.586]$} & & [0.997] & & {$[0.706]$} \\
\hline
\end{tabular}

Source: Authors' calculations.

Note: White's heteroscedasticity-consistent standard errors are reported in parentheses. ** and * denote significance at the 5 percent and 10 percent level, respectively. Capital flows and current account balance are expressed as a percent of GDP. Interest rates, forward premiums, and EMBI spreads are expressed in percent. The period is 2000:M1-2008:M8. 
Figure 1. Private Capital Flows

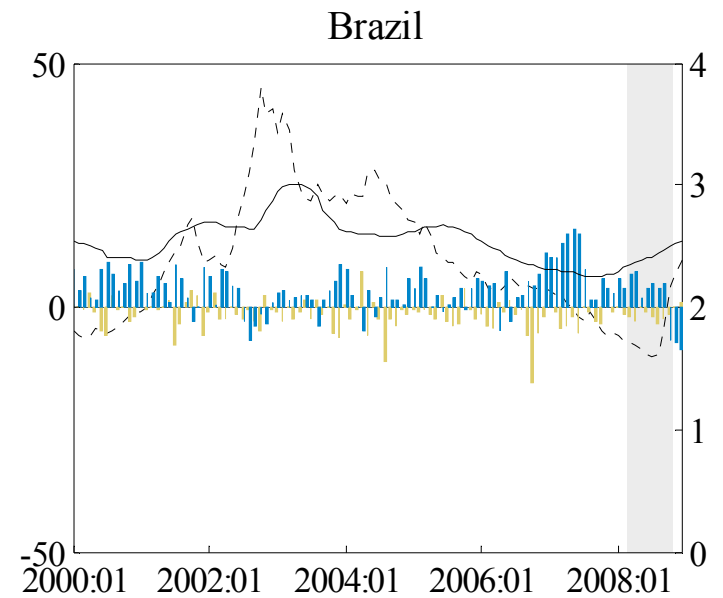

Thailand

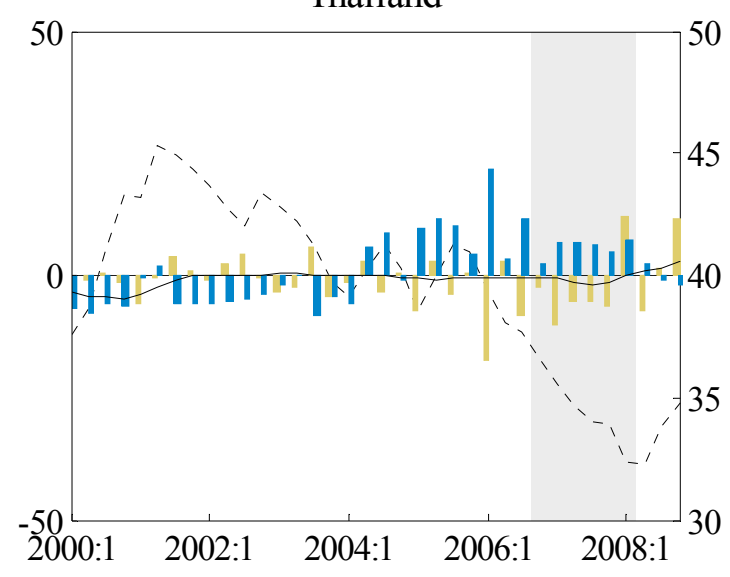

Colombia
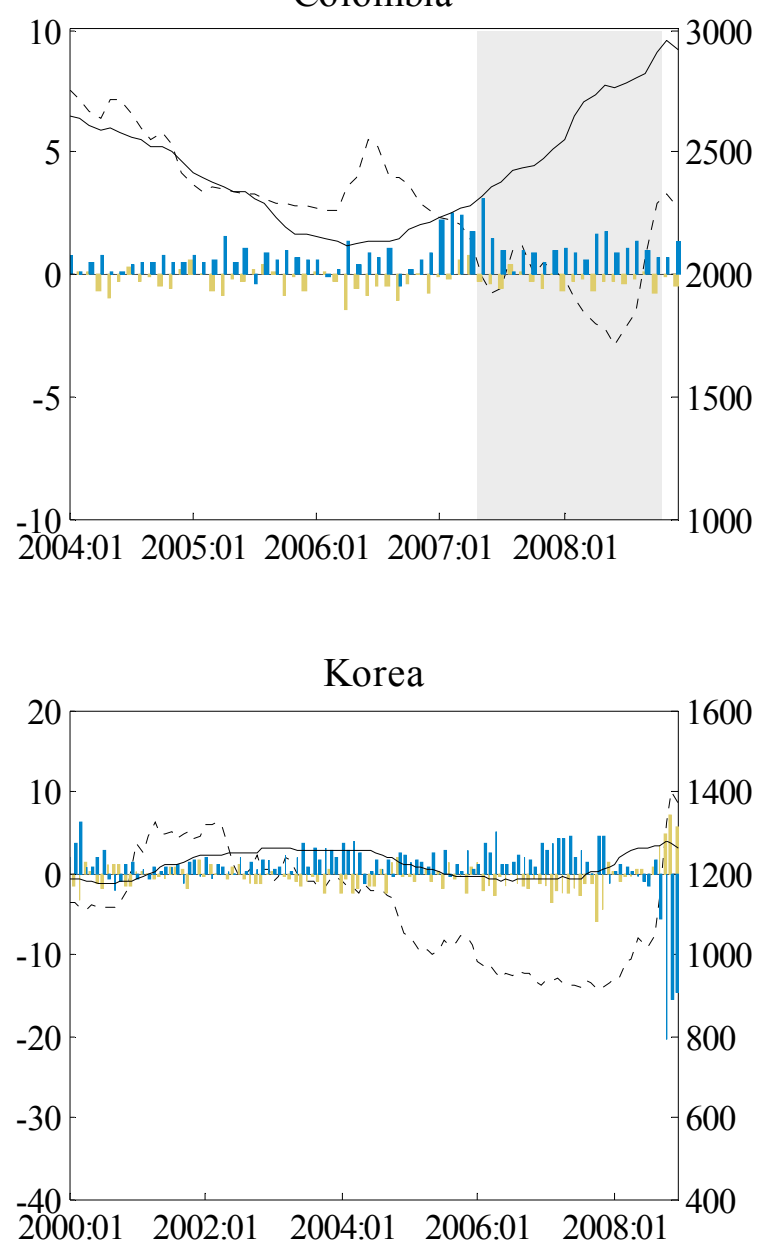

Capital inflows (in percent of GDP, left)

Capital outflows (in percent of GDP, left)

Interest rate differential (in percent, left)

Exchange rate (nominal, right)

Sources: International Financial Statistics and Balance of Payments Statistics databases; central bank websites; and authors' calculations.

Note: A shaded area in the figure indicates the tax or URR period. Nominal exchange rates are expressed as national currency over the U.S. dollar. Interest rate differential refers to the difference between the money market rates in the country and in the United States. 
Figure 2. Evolution of Capital Controls
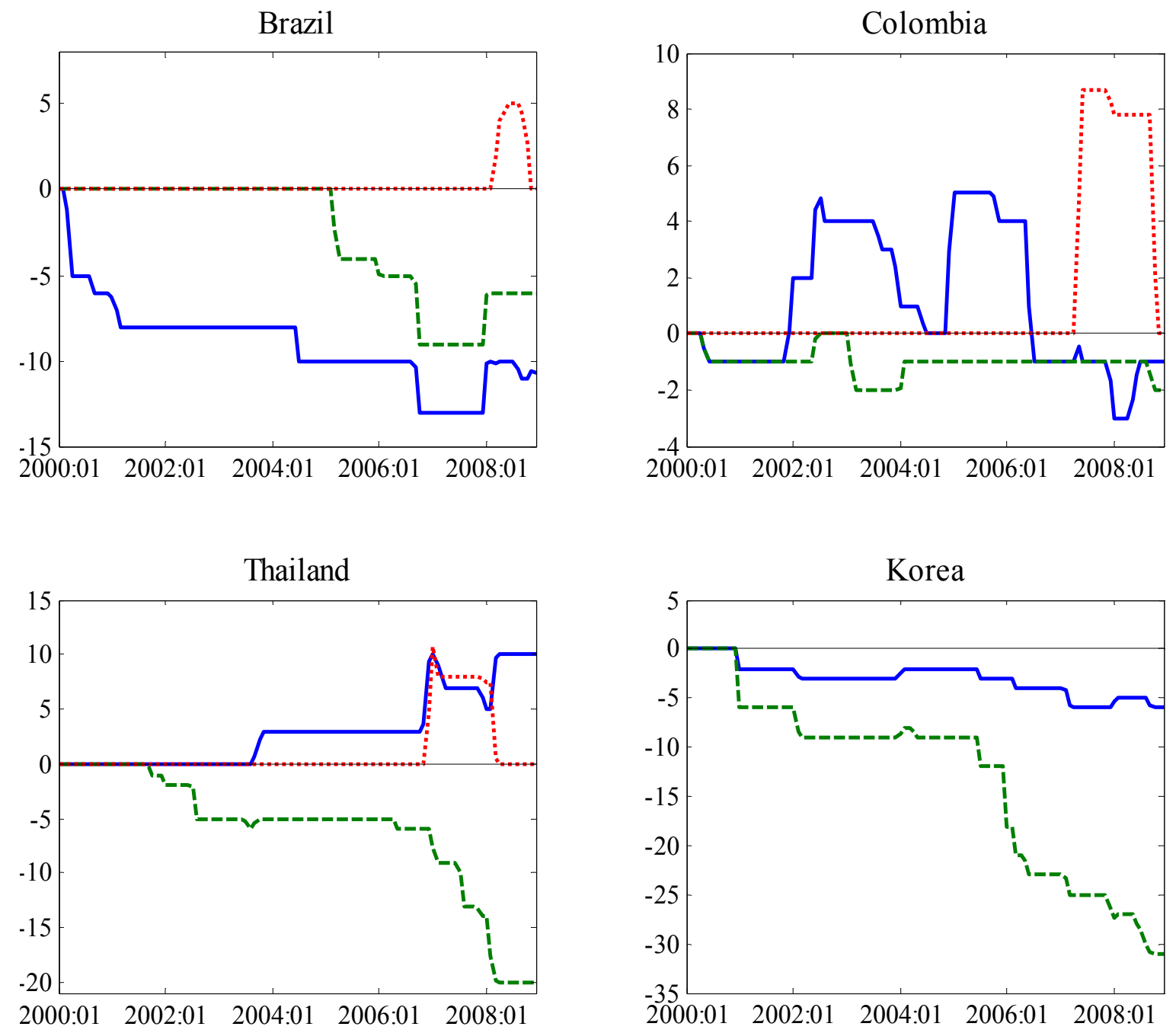

Sources: AREAER database; and authors' calculations.

Note: For indices of inflow and outflow controls, higher values indicate that the transactions are subject to more restrictions. For the tax and URR indices, higher values indicate that the regulation applies to more types of inflows. 
Figure 3. Responses to the Tax in Brazil

Taxindex (coverage and effective rate)

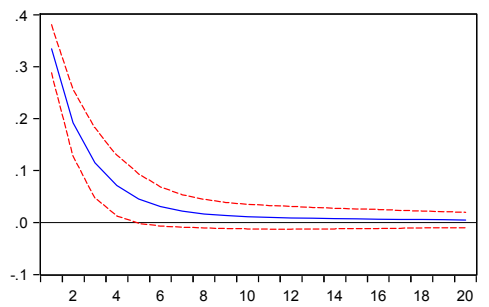

Interest rate differential

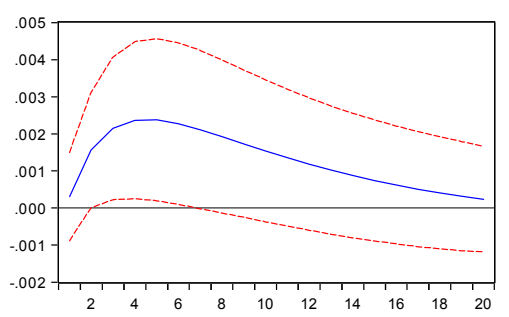

Inflow control index

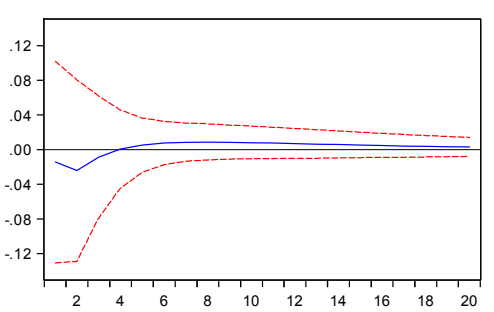

Total net capital flows (in percent of GDP)

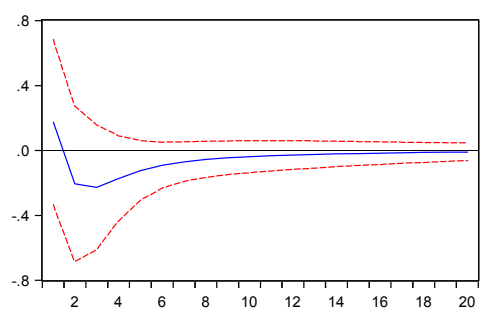

Outflow control index

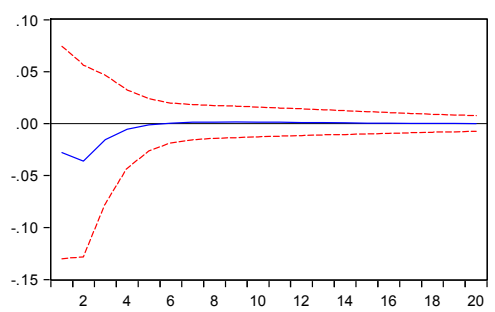

Real exchange rate (in log)

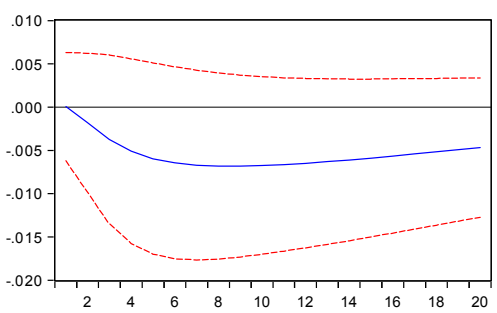

Source: Authors' calculations.

Note: The panels show responses to a one standard deviation shock to the tax index. The estimation includes one lag. The dashed lines show 95 percent confidence interval. Endogenous variables include the tax index, inflow control index, outflow control index, interest rate differentials, net total capital flows, and real exchange rates. Exogenous variables include the domestic business cycle, U.S. business cycle, EMBI spread, ICRG, VIX, and lagged current account balance. The period is 2000:M1-2008:M8.

\section{Figure 4. Responses to the Tax in Brazil; Composition of the Flows}

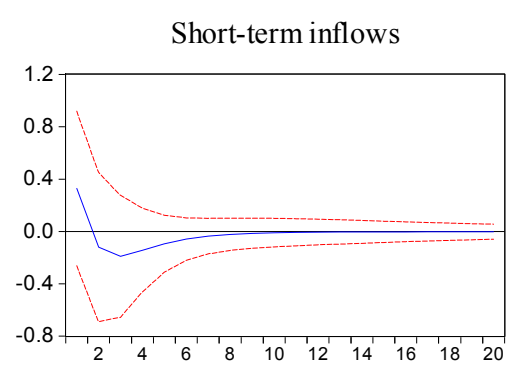

Long-term inflows

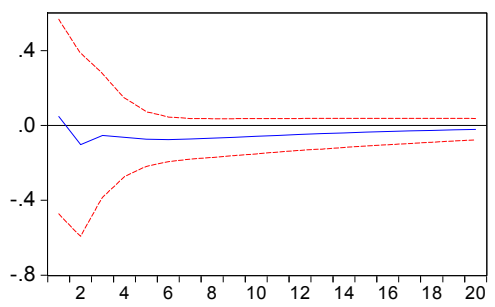

Short-term outflows

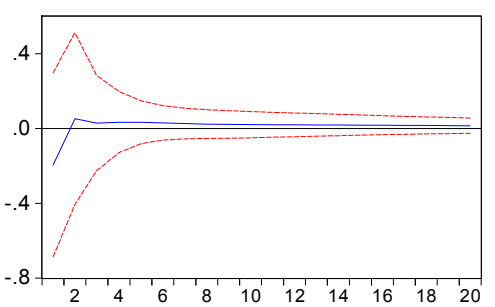

Long-term outflows

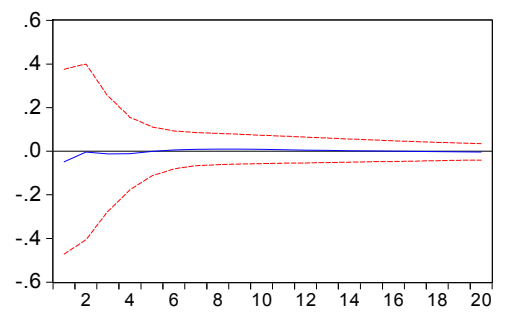

Source: Authors' calculations.

Note: The panels show responses to a one standard deviation shock to the tax index. The estimation includes one lag. The dashed lines show the 95 percent confidence interval. Endogenous variables include the tax index, inflow control index, outflow control index, interest rate differentials, net capital flows (short-term inflows, short-term outflows, long-term inflows, long-term outflows), and real exchange rates. Exogenous variables include the domestic business cycle, U.S. business cycle, EMBI spread, ICRG, VIX, and lagged current account balance. The period is 2000:M1-2008:M8. 
Figure 5. Responses to the Unremunerated Reserve Requirement in Colombia

URR index(coverage and tax equivalent rate)

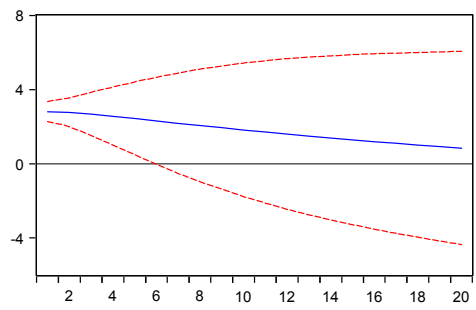

Interest rate differential

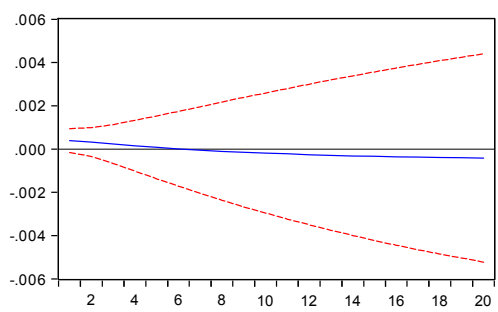

Inflow control index

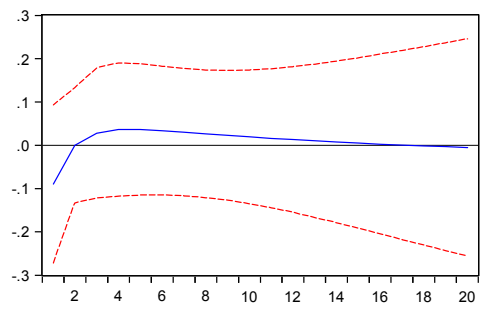

Total net capital flows (in percent of GDP)

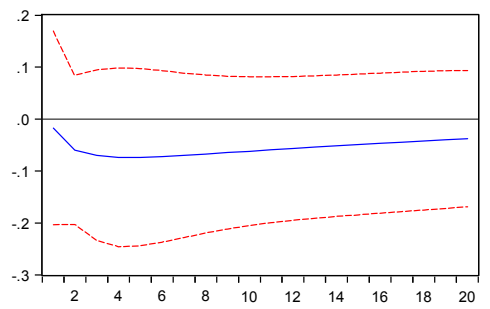

Outflow control index

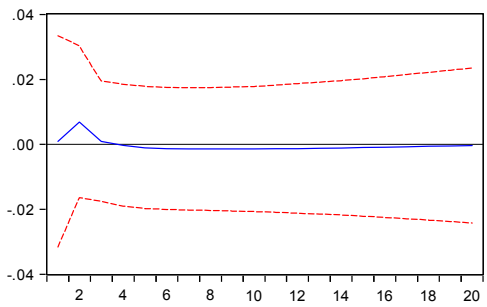

Real exchange rate (in $\log$ )

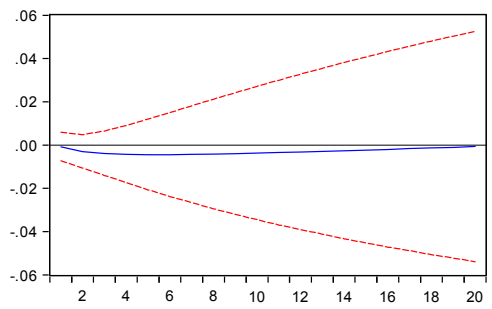

Source: Authors' calculations.

Note: The panels show responses to a one standard deviation shock to the URR index. The estimation includes one lag. The dashed lines show the 95 percent confidence interval. Endogenous variables include the URR index, inflow control index, outflow control index, interest rate differentials, net capital flows, and real exchange rates. Exogenous variables include the domestic business cycle, U.S. business cycle, EMBI spread, ICRG, VIX, and lagged current account balance. The period is 2004:M1-2008:M8.

\section{Figure 6. Responses to the Unremunerated Reserve Requirement in Colombia Six Months after its Introduction}

URR index (coverage and tax equivalent rate)

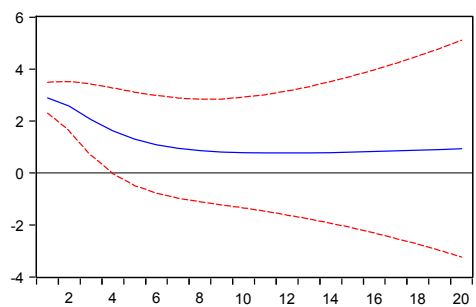

Interest rate differential

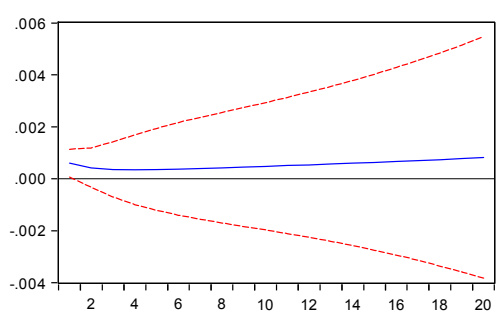

Inflow controlindex

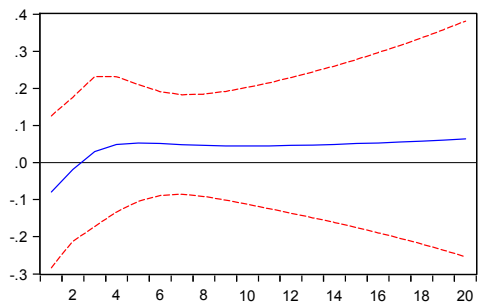

Total net capital flows (in percent of GDP)

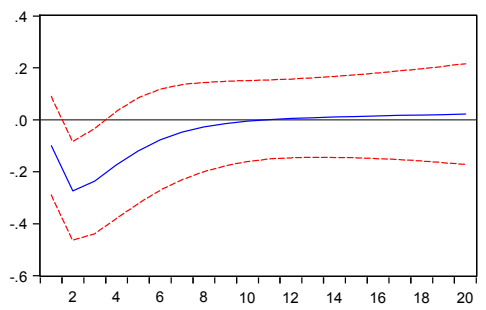

Outflow control index

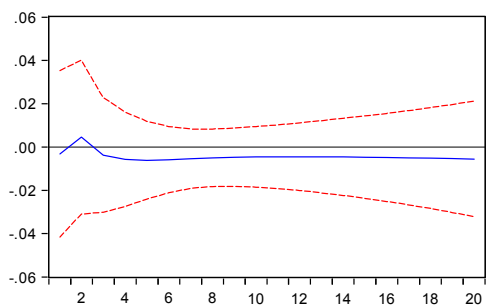

Real exchange rate (in $\log$ )

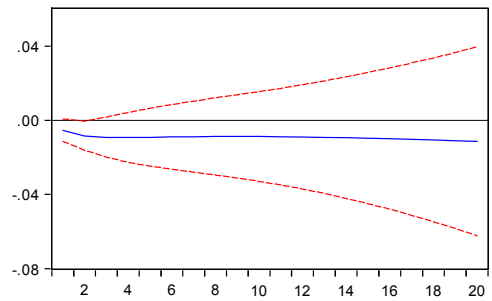

Source: Authors' calculations.

Note: The panels show responses to a one standard deviation shock to the URR index. The estimation includes one lag. The dashed lines show the 95 percent confidence interval. Endogenous variables include the URR index, inflow control index, outflow control index, interest rate differentials, net capital flows, and real exchange rates. Exogenous variables include the domestic business cycle, U.S. business cycle, EMBI spread, ICRG, VIX, and lagged current account balance. The period is 2004:M1-2007:M12. 
Figure 7. Responses to the Unremunerated Reserve Requirement in Colombia Six Months after its Introduction; Composition of the Flows

Short-term inflows

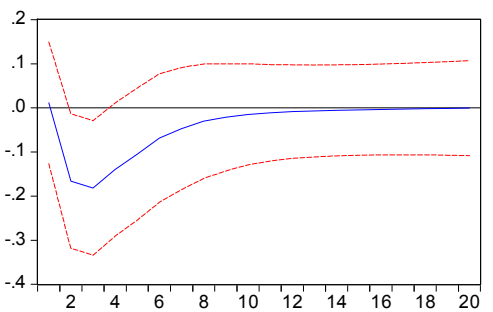

Long-term inflows

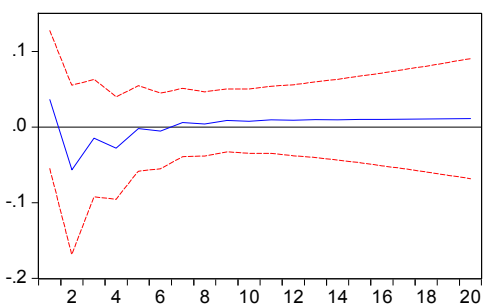

Short-term outflows

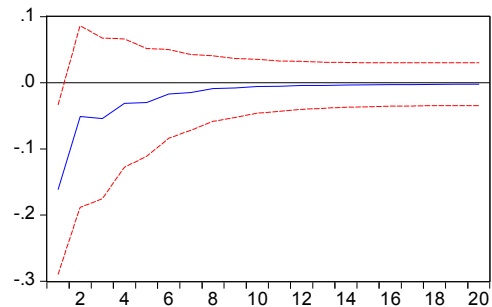

Long-term outflows

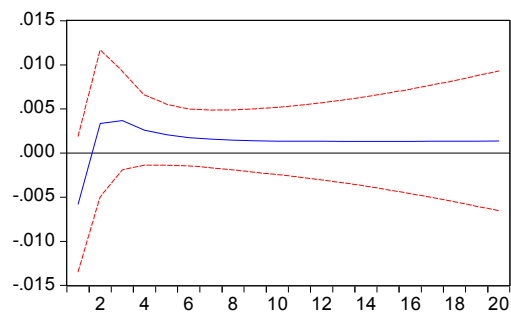

Source: Authors' calculations.

Note: The panels show responses to a one standard deviation shock to the URR index. The estimation includes one lag. The dashed lines show the 95 percent confidence interval. Endogenous variables include the URR index, inflow control index, outflow control index, interest rate differentials, net capital flows (short-term inflows, short-term outflows, long-term inflows, long-term outflows), and real exchange rates. Exogenous variables include the domestic business cycle, U.S. business cycle, EMBI spread, ICRG, VIX, and lagged current account balance. Long-term flows refer to direct investment, and short-term flows refer to the sum of portfolio investment and other investment. The period is 2004:M1-2007:M12.

\section{Figure 8. Responses to the Unremunerated Reserve Requirement in Thailand}

URR index (coverage and tax equivalent rate)

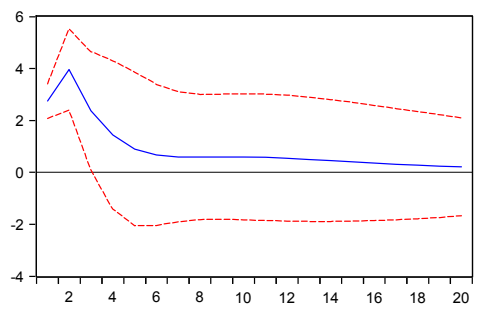

Interest rate differential

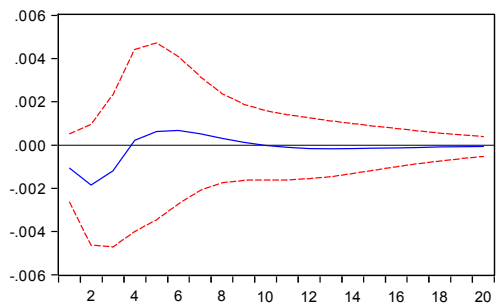

Inflow control index

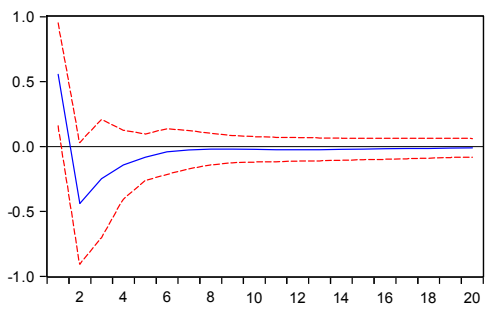

Total net capital flows (in percent of GDP)

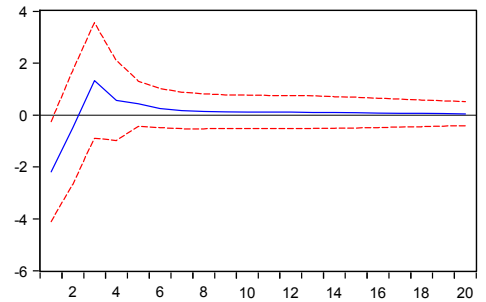

Outflow control index

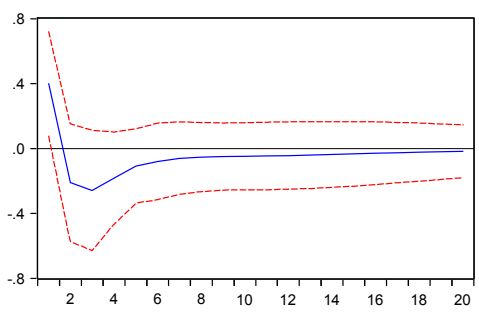

Real exchange rate (in log)

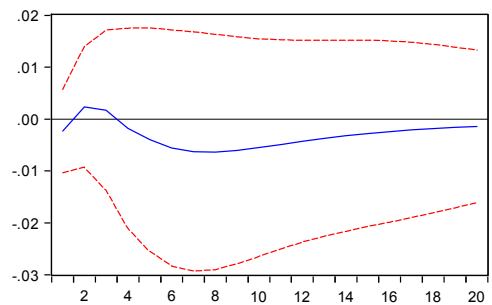

Source: Authors' calculations.

Note: The panels show responses to a one standard deviation shock to the URR index. The estimation includes one lag. The dashed lines show the 95 percent confidence interval. Endogenous variables include the URR index, inflow control index, outflow control index, interest rate differentials, net total capital flows, and real exchange rates. Exogenous variables include the domestic business cycle, U.S. business cycle, ICRG, VIX, and lagged current account balance. The period is 2000:Q1-2008:Q2. 


\section{Figure 9. Responses to the Unremunerated Reserve Requirement in Thailand; Composition of the Flows}
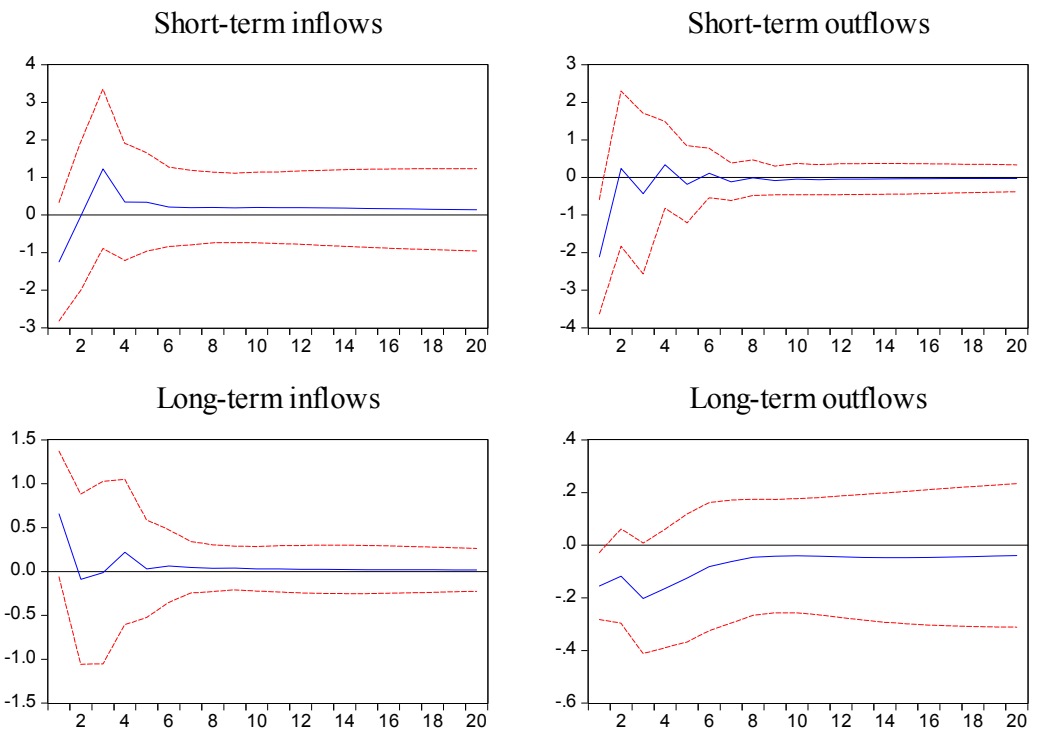

Source: Authors' calculations.

Note: The panels show responses to a one standard deviation shock to the URR index. The estimation includes one lag. The dashed lines show the 95 percent confidence interval. Endogenous variables include the URR index, inflow control index, outflow control index, interest rate differentials, net capital flows (short-term inflows, short-term outflows, long-term inflows, long-term outflows), and real exchange rates. Exogenous variables include the domestic business cycle, U.S. business cycle, ICRG, VIX, and lagged current account balance. The period is 2000:Q1-2008:Q2.

\section{Figure 10. Responses to Other Inflow Controls in Thailand}

Interest rate differential

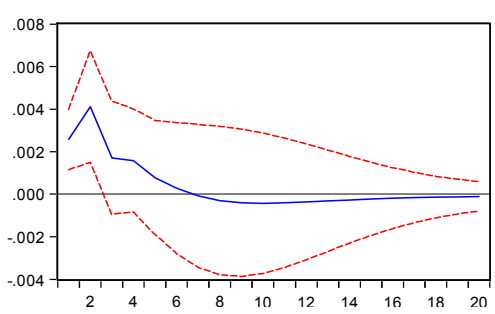

Total net capital flows (in percent of GDP)

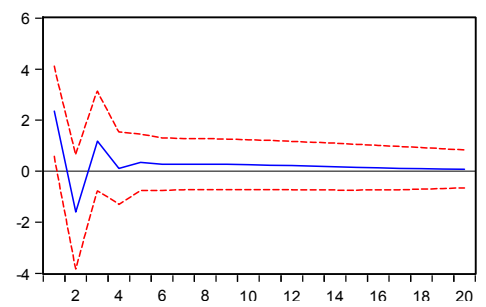

Real exchange rate (in log)

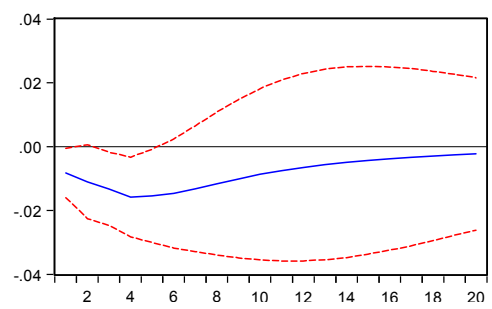

Source: Authors' calculations.

Note: The panels show responses to a one standard deviation shock to the inflow control index. The estimation includes one lag. The dashed lines show the 95 percent confidence interval. Endogenous variables include the URR index, inflow control index, outflow control index, interest rate differentials, net capital flows (short-term inflows, short-term outflows, long-term inflows, long-term outflows), and real exchange rates. Exogenous variables include the domestic business cycle, U.S. business cycle, ICRG, VIX, and lagged current account balance. The period is 2000:Q1-2008:Q2. 
Figure 11. Responses to the Outflow Controls in Korea

Inflow control index

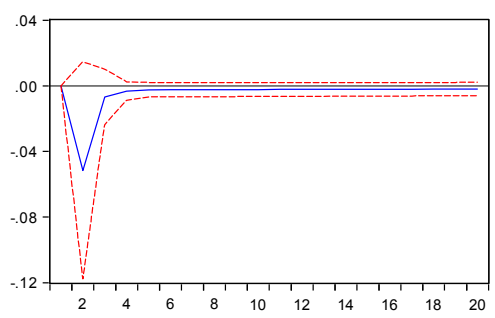

Total net capital flows (in percent of GDP)

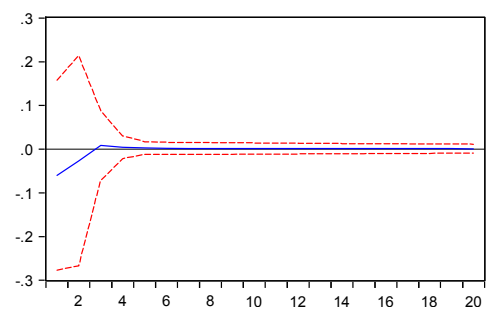

Outflow control index

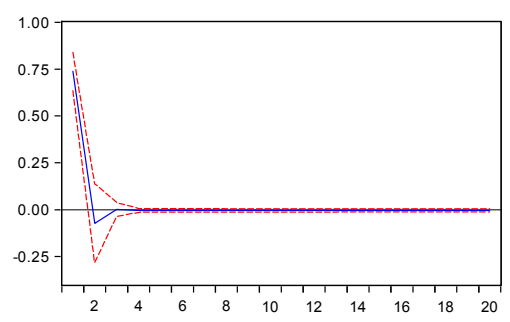

Real exchange rate (in log)

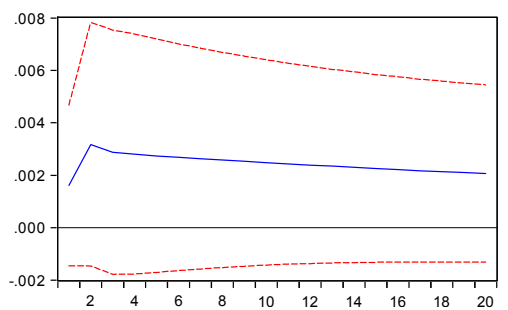

Interest rate differential

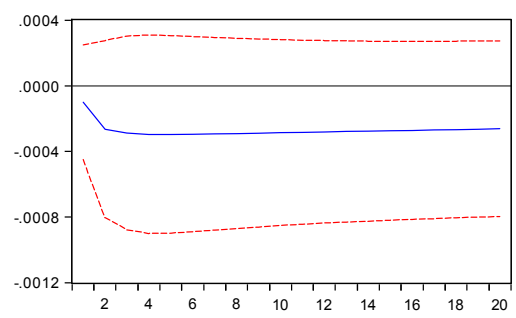

Source: Authors' calculations.

Note: The panels show responses to a one standard deviation shock to the outflow control index. The estimation includes one lag. The dashed lines show the 95 percent confidence interval. Endogenous variables include the inflow control index, outflow control index, interest rate differential, net capital flows, and real exchange rates. Exogenous variables include the domestic business cycle, U.S. business cycle, ICRG, VIX, and lagged current account balance. The period is 2000:M1-2008:M8.

\section{Figure 12. Responses to the Outflow Controls in Korea, Composition of the Flows}

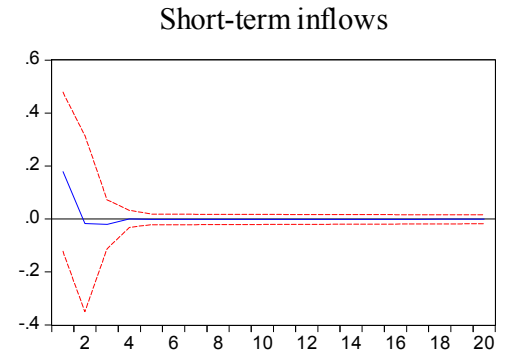

Long-term inflows

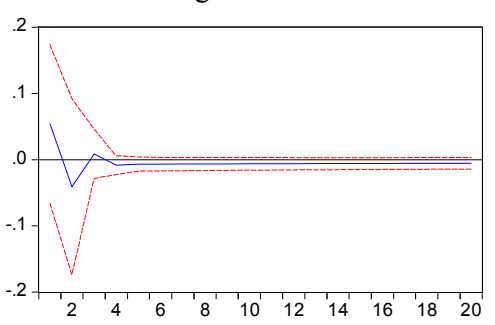

Short-term outflows

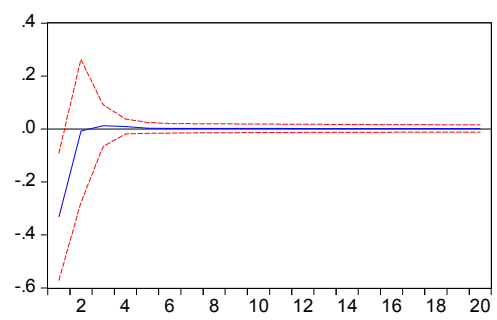

Long-term outflows

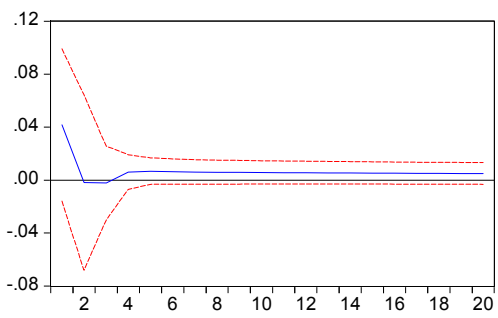

Source: Authors' calculations.

Note: The panels show responses to a one standard deviation shock to the outflow control index. The estimation includes one lag. The dashed lines show the 95 percent confidence interval. Endogenous variables include the inflow control index, outflow control index, interest rate differential, net capital flows (short-term inflows, short-term outflows, long-term inflows, long-term outflows), and real exchange rates. Exogenous variables include the domestic business cycle, U.S. business cycle, ICRG, VIX, and lagged current account balance. The period is 2000:M1-2008:M8. 


\section{Appendix I. Series Definition, Source, and Coverage}

\begin{tabular}{|c|c|c|c|c|c|}
\hline Variables & Country & Freq. & Source & Statistics & Description/Notes \\
\hline \multirow[t]{4}{*}{ Private capital flows } & All & Q & IMF BOPS & & \multirow{4}{*}{$\begin{array}{l}\text { Private capital flows are obtained by stripping out } \\
\text { capital flows (portfolio investment liabilities and other } \\
\text { investments liabilities and assets) by general } \\
\text { government and monetary authority. }\end{array}$} \\
\hline & Brazil & M & Central bank & Balance of Payments & \\
\hline & Colombia & $\mathrm{M}$ & Central bank & Balanza Cambiaria & \\
\hline & Korea & $\mathrm{M}$ & Central bank & Balance of Payments & \\
\hline \multirow[t]{4}{*}{ Nominal GDP, real GDP } & All & Q & IMF IFS & & \multirow{4}{*}{$\begin{array}{l}\text { Seasonality is adjusted by the authors. Real GDP is } \\
\text { obtained by deflating the nominal GDP by the } \\
\text { consumer price index. We extrapolate the growth rate } \\
\text { of the industrial production index into the quarterly } \\
\text { GDP series to obtain the monthly GDP series. }\end{array}$} \\
\hline & Brazil & M & Central bank & Monthly Gross Domestic Product & \\
\hline & \multicolumn{2}{|c|}{ Colombia M } & Central bank & Manufacturing industry real production index & \\
\hline & Korea & $\mathrm{M}$ & IMF IFS & Industrial production index & \\
\hline Exchange rates & All & $\mathrm{Q}, \mathrm{M}$ & IMF IFS & & Period average \\
\hline Interest rates & All & $\mathrm{Q}, \mathrm{M}$ & IMF IFS & Money market rate & Period average \\
\hline \multirow{4}{*}{$\begin{array}{l}\text { Forward exchange rates } \\
\text { EMBIG Sovereign } \\
\text { Spread }\end{array}$} & All & $\mathrm{Q}, \mathrm{M}$ & Bloomberg & & \multirow{4}{*}{$\begin{array}{l}\text { Period average } \\
\text { Period average }\end{array}$} \\
\hline & & & & & \\
\hline & Brazil & $\mathrm{Q}, \mathrm{M}$ & Bloomberg & JPMorgan EMBIG sovereign spread: Brazil & \\
\hline & \multicolumn{2}{|c|}{ Colombia Q, M } & Bloomberg & JPMorgan EMBIG sovereign spread: Colombia & \\
\hline ICRG & All & $\mathrm{Q}, \mathrm{M}$ & PRS group & Composite risk & \\
\hline VIX & & $\mathrm{Q}, \mathrm{M}$ & Bloomberg & & Period average \\
\hline
\end{tabular}

Note: Quarterly data start in 2000:Q1 and end with 2008:Q2. Monthly data start in January 2000 and end with August 2008. Due to limited data availability, Colombia's monthly data start in January 2004. BOPS refers to Balance of Payment Statistics database, and IFS refers to International Financial Statistics database. 
Appendix II. Summary of Stationarity Test

\begin{tabular}{|c|c|c|c|c|c|}
\hline Indicator & Transformation & Brazil & Colombia & Thailand & Korea \\
\hline Net total flows & $\% \mathrm{GDP}$ & $* *$ & $* * *$ & $* * *$ & $* * *$ \\
\hline Net short-term flows & $\% \mathrm{GDP}$ & $* * *$ & $* * *$ & $* * *$ & $* * *$ \\
\hline Net long-term flows & $\%$ GDP & $* * *$ & $* * *$ & $* * *$ & $* * *$ \\
\hline Total inflows & $\% \mathrm{GDP}$ & $* * *$ & $* * *$ & $* * *$ & $* * *$ \\
\hline Total short-term inflows & $\% \mathrm{GDP}$ & $* * *$ & $* * *$ & $2 /$ & $* * *$ \\
\hline Total long-term inflows & $\% \mathrm{GDP}$ & $* * *$ & $* * *$ & $* * *$ & $* * *$ \\
\hline Total outflows & $\%$ GDP & $* * *$ & $* * *$ & $* * *$ & $* * *$ \\
\hline Total short-term outflows & $\% \mathrm{GDP}$ & $* * *$ & $* * *$ & $* * *$ & $* * *$ \\
\hline Total long-term outflows & $\% \mathrm{GDP}$ & $* * *$ & $* * *$ & $*$ & $* * *$ \\
\hline URR/Tax index & Level & $2 /$ & $2 /$ & $2 /$ & n.a. \\
\hline Inflow control index & 1st difference & $* * *$ & $* * *$ & $* * *$ & $* * *$ \\
\hline Outflow control index & 1st difference & $* * *$ & $* * *$ & $* * *$ & $* * *$ \\
\hline Interest rate differential & Difference to benchmark & $*$ & $2 /$ & & \\
\hline Spot exchange rate & $\log$ & & & & \\
\hline Real exchange rate & $\log$ & & & & \\
\hline Forward premium & Level & $* * *$ & $* * *$ & $2 /$ & $2 /$ \\
\hline Domestic business cycle & HP filtered & $* * *$ & $2 /$ & $2 /$ & $* * *$ \\
\hline Foreign business cycle & HP filtered & $* *$ & $2 /$ & $2 /$ & $* *$ \\
\hline ICGR index & 1st difference & $* * *$ & $* * *$ & $* * *$ & $* * *$ \\
\hline EMBIG sovereign spread & Level & $*$ & $2 /$ & n.a. & n.a. \\
\hline VIX & Level & $2 /$ & $2 /$ & $2 /$ & $2 /$ \\
\hline Current account balance & $\% \mathrm{GDP}$ & $*$ & $* *$ & $2 /$ & $* * *$ \\
\hline Frequency & & Monthly & Monthly & Quarterly & Monthly \\
\hline
\end{tabular}

Notes:

1/ An augmented Dickey-Fuller test is performed for each model. ***,**, and * indicate the null hypothesis of a unit root is rejected at the $1 \%, 5 \%$, and $10 \%$ significance level, respectively. The lag for each model is chosen according to the Schwarz information criterion, with the maximum lag 4 for a quarterly series and 12 for a monthly series. The sample periods are January 2000 to August 2008 for Brazil and Korea, January 2004 to August 2008 for Colombia, and 2000:Q1 to 2008:Q2 for Thailand.

$2 /$ Stationarity can be confirmed at least at the $10 \%$ significance level if the sample period is extended to cover 1999:Q1-2008:Q2 or 1999:M1-2008:M12. Because our evidence of stationarity is weak, our analysis may underestimate the actual effects on capital flows that are stationary.

$3 /$ n.a. indicates the absence of the corresponding series in the data set. 


\section{Appendix III. Selected Capital Account Management Measures}

\begin{tabular}{|c|c|}
\hline $\begin{array}{l}\text { Country (analyzed } \\
\text { period) and Concerns }\end{array}$ & Policy_Major Measures \\
\hline $\begin{array}{l}\text { Brazil } \\
\text { (2000:M1-2008:M8) } \\
\text { Currency appreciation } \\
\text { Credit boom }\end{array}$ & $\begin{array}{l}\text { Tax: On March 17, 2008, the IOF tax was raised to } 1.5 \text { percent on the entry of foreign funds in the settlement of } \\
\text { investments in the financial and capital markets and extended in May to similar transactions made by means of } \\
\text { simultaneous operations. Exemptions were applied to funds related to equities, equities derivatives, public offerings, and } \\
\text { subscription of shares. The } 1.5 \text { percent tax was eliminated in October } 2008 \text {. } \\
\text { Outflow liberalization: The limits on employee stock option programs and on FDI by nonfinancial private enterprises and } \\
\text { the approval requirement on certain personal capital transactions were lifted in March 2005. The controls on individuals' } \\
\text { and corporations' transfers abroad by were abolished in September } 2006 \text {. }\end{array}$ \\
\hline $\begin{array}{l}\text { Colombia } \\
(2000: Q 1-2008: Q 2) \\
\text { Currency appreciation } \\
\text { Credit boom }\end{array}$ & $\begin{array}{l}\text { URR: Foreign portfolio investments, advance payments of more than four months, financial credits, guarantees, sureties, } \\
\text { and financial backup facilities to residents were made subject to a six-month } 40 \text { percent URR on May } 6,2007 \text {. Foreign } \\
\text { trade financing was made subject to a } 12 \text {-month deposit of } 11 \text { percent in pesos or a deposit of } 20 \text { percent in U.S. dollars. } \\
\text { Penalties for early withdrawal of investments subject to the URR were reduced, and portfolio investments in the primary } \\
\text { issuance of equities or in institutional funds were made exempt from the URR in December } 2007 \text {. The penalties were later } \\
\text { increased in June } 2008 \text {. The URR on portfolio inflows was raised from } 40 \text { percent to } 50 \text { percent in May 2008. The URR } \\
\text { was eliminated October 9, } 2008 \text {. } \\
\text { Inflow controls: The deposit requirement on external financing was lifted in May } 2000 \text {. Nonresidents' purchase of fixed- } \\
\text { income securities was limited to } 20 \text { percent of the issue in June; the issuance of securities index derivatives was permitted } \\
\text { in } 2002 \text {. Controls on the use of balances deposited in nonresident foreign currency accounts were lifted in } 2003 \text {. A one- } \\
\text { year minimum holding period was introduced on nonresidents' portfolio investments from December } 2004 \text { through June } \\
\text { 2006. A minimum stay of two years was imposed on FDI in May } 2008 \text {. } \\
\text { Limits on banks' leverage were introduced in } 2001 \text {. Banks' gross exposure in the foreign exchange derivative market was } \\
\text { limited to } 500 \text { percent of capital in May } 2007 \text { and increased to } 550 \text { percent in May } 2008 \text {. }\end{array}$ \\
\hline $\begin{array}{l}\text { Korea } \\
\text { (2000:M1-2008:M8) } \\
\text { Currency appreciation } \\
\text { Unhedged foreign } \\
\text { exchange lending }\end{array}$ & $\begin{array}{l}\text { Outflow liberalization: Limits on deposits abroad were eliminated. The limit on lending to nonresidents was increased } \\
\text { and residents' personal capital transfers were liberalized in } 2001 \text {. The ceiling on commercial credits was increased in } \\
2002 \text {. The limit on individuals' FDI was raised to US } \$ 3 \text { million and on certain real estate purchases to US } \$ 500,000 \text { in } \\
\text { 2005. Following a further increase, they were eliminated in March } 2006 \text {. The rules for the repatriation of proceeds from } \\
\text { capital transactions were further eased, and all approval requirements for capital transactions were changed to notification } \\
\text { requirements in January } 2006 \text {. The threshold for prior notification of won-denominated loans to nonresidents was raised } \\
\text { to W } 10 \text { billion in } 2006 \text { and to W } 30 \text { billion in 2007. Real estate purchases and establishment of bank branches abroad } \\
\text { were further liberalized during } 2007-08 \text {. }\end{array}$ \\
\hline
\end{tabular}

(C)International Monetary Fund. Not for Redistribution 


\begin{tabular}{|c|c|}
\hline $\begin{array}{l}\text { Country (analyzed } \\
\text { period) and Concerns }\end{array}$ & Policy_Major Measures \\
\hline $\begin{array}{l}\text { Thailand } \\
\text { (2000:Q1-2008:Q2) } \\
\text { Currency appreciation }\end{array}$ & 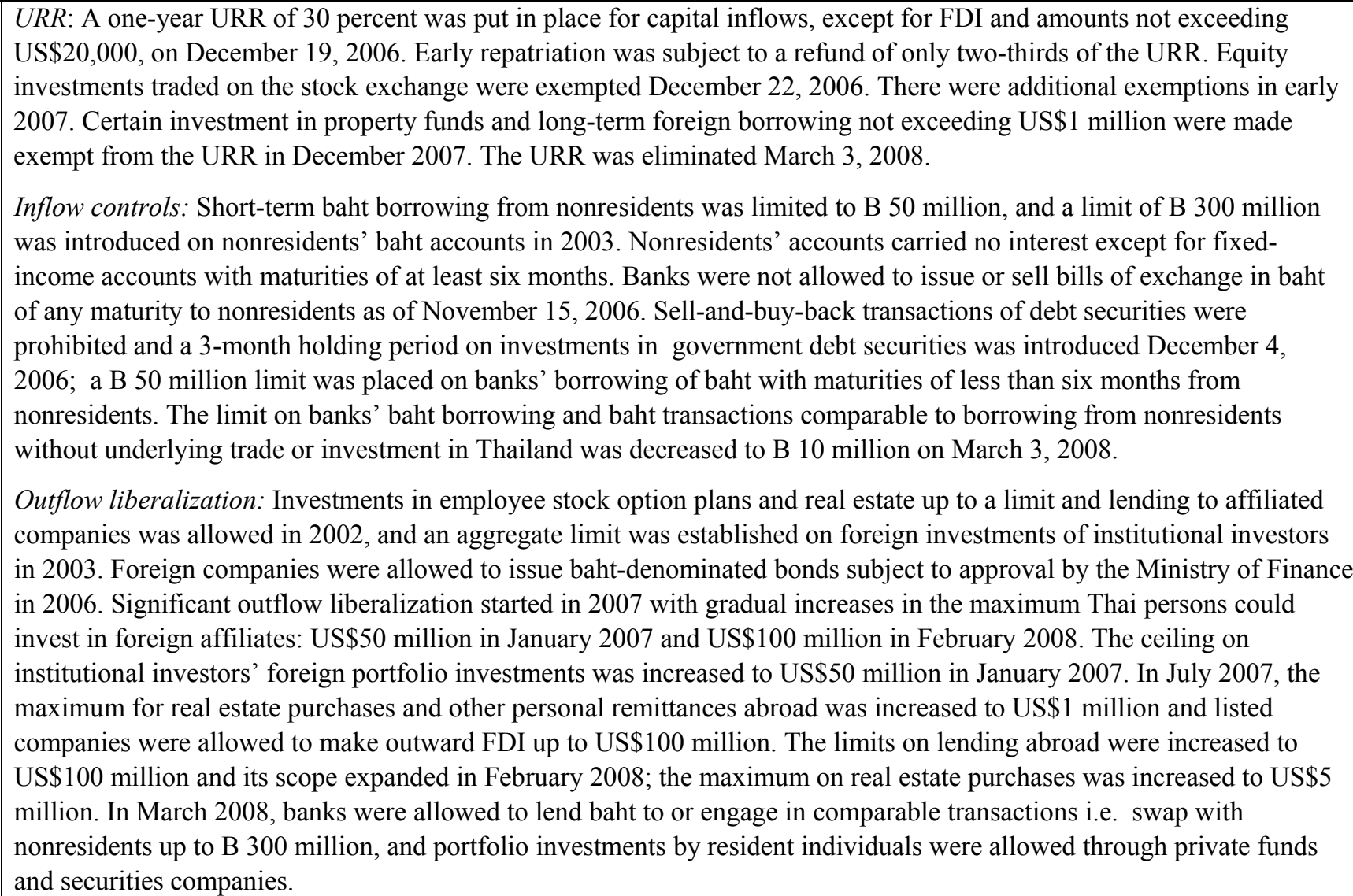 \\
\hline
\end{tabular}




\section{REFERENCES}

Ariyoshi, Akira, Karl Habermeier, Bernard Laurens, İnci Ötker-Robe, Jorge Ivan CanalesKriljenko, and Andrei Kirilenko, 2000, Capital Controls: Country Experiences with Their Use and Liberalization, IMF Occasional Paper No. 190 (Washington D.C.: International Monetary Fund).

Baba, Chikako, and Annamaria Kokenyne, 2011, "Capital Controls and Prudential Measures: Emerging Markets' Experiences with Managing Capital Inflows" (unpublished; Washington D.C.: International Monetary Fund).

Cardoso, Eliana, and Ilan Goldfajn, 1998, "Capital Flows to Brazil: The Endogeneity of Capital Controls," IMF Staff Papers, Vol. 45, No.1, pp. 161-202.

Carvalho, Bernardo S. de M., and Macio G. P. Garcia, 2008, "Ineffective Controls on Capital Inflows under Sophisticated Financial Markets: Brazil in the Nineties," in Financial Markets Volatility and Performance in Emerging Markets, A National Bureau of Economic Research Conference Report, ed. by Sebastoam Edwards and Marcio G. P. Garcia (Chicago: University of Chicago Press).

Chung, J.-H., and S. Ni, 2002, “An Empirical Analysis on Government Capital Controls and International Capital Flows in Korea," Applied Economics Letters, Vol. 9, No. 14, pp. 919-23.

Clements, Benedict J., and Herman Kamil, 2009, "Are Capital Controls Effective in the 21st Century? The Recent Experience of Colombia,” IMF Working Paper 09/30 (Washington D.C.: International Monetary Fund).

Coelho, Bruno, and Kevin P. Gallagher, 2010, "Capital Controls and 21st Century Financial Crises: Evidence from Colombia and Thailand," Political Economy Research Institute Working Paper No. 213 (Amherst, Massachusetts: Political Economy Research Institute).

Concha, Alvaro, and Arturo Jose Galindo, 2009, "An Assessment of Another Decade of Capital Controls in Colombia: 1998-2008," Inter-American Development Bank Working Paper (Washington D.C.: Inter-American Development Bank).

Cowan, Kevin, and José De Gregorio, 2007, "International Borrowing, Capital Controls and the Exchange Rate: Lessons from Chile," in Capital Controls and Capital Flows in Emerging Economies: Policies, Practices and Consequences, ed. by Sebastian Edwards (Cambridge, Massachusetts: National Bureau of Economic Research and The University of Chicago Press). 
David, Antonio C., 2007, "Revisiting Price-based Controls on Capital Inflows in a 'Sophisticated' Emerging Market,' World Development, Vol. 35, No. 8, pp. 1329-40.

De Gregorio, José, Sebastian Edwards, and Rodrigo O. Valdés, 2000, "Controls on Capital Inflows: Do They Work?” Journal of Development Economics, Vol. 63, No. 1, pp. 5983.

Goldfajn, Ilan, and André Minella, 2005, "Capital Flows and Controls in Brazil: What Have We Learned?" NBER Working Papers (Cambridge, Massachusetts: National Bureau of Economic Research).

International Monetary Fund (IMF), 2010, "Global Liquidity Expansion: Effects on 'Receiving' Economies and Policy Response Options," Chapter 4 in Global Financial Stability Report, World Economic and Financial Surveys (Washington D.C., April). , 2011, "Recent Experiences in Managing Capital Inflows-Cross-Cutting Themes and Possible Guidelines," IMF Policy Paper (Washington D.C., April).

Jittrapanun, Thawatchai, and Suthy Prasartset, 2009, Hot Money and Capital Controls in Thailand, TWN Global Economy Series (Penang: Third World Network).

Magud, Nicolas, and Carmen M. Reinhart, 2007, "Capital Controls: An Evaluation," in Capital Controls and Capital Flows in Emerging Economies: Policies, Practices and Consequences, ed. by Sebastian Edwards (Cambridge, Massachusetts: National Bureau of Economic Research).

Ostry, Jonathan D., Atish R. Ghosh, Karl Habermeier, Marcos Chamon, Mahvash S. Qureshi, and Dennis B.S. Reinhardt, 2010, "Capital Inflows: The Role of Controls," IMF Staff Position Note 10/04 (Washington D.C.: International Monetary Fund).

Thaicharoen, Yunyong, and Nasha Ananchotikul, 2008, "Thailand's Experiences with Rising Capital Flows: Recent Challenges and Policy Responses," in Financial Globalisation and Emerging Market Capital Flows, ed. by Bank for International Settlements (Basel). 